\title{
Non-Nucleoside Agonists of the Adenosine Receptors: An Overview
}

\author{
Diego Dal Ben ${ }^{1}$, Catia Lambertucci, Michela Buccioni, Aleix Martí Navia, Gabriella Marucci, \\ Andrea Spinaci ${ }^{(D)}$ and Rosaria Volpini * (D) \\ School of Pharmacy, Medicinal Chemistry Unit, University of Camerino, 62032 Camerino, MC, Italy; \\ diego.dalben@unicam.it (D.D.B.); catia.lambertucci@unicam.it (C.L.); michela.buccioni@unicam.it (M.B.); \\ aleix.martinavia@unicam.it (A.M.N.); gabriella.marucci@unicam.it (G.M.); andrea.spinaci@unicam.it (A.S.) \\ * Correspondence: rosaria.volpini@unicam.it; Tel.: +39-737-402278
}

Received: 9 September 2019; Accepted: 5 October 2019; Published: 8 October 2019

\begin{abstract}
Potent and selective adenosine receptor (AR) agonists are of pharmacological interest for the treatment of a wide range of diseases and conditions. Among these derivatives, nucleoside-based agonists represent the great majority of molecules developed and reported to date. However, the limited availability of compounds selective for a specific $A R$ subtype (i.e., $A_{2 B} A R$ ) and a generally long and complex synthetic route for largely substituted nucleosides are the main drawbacks of this category of molecules. Non-nucleoside agonists represent an alternative set of compounds able to stimulate the AR function and based on simplified structures. This review provides an updated overview on the structural classes of non-nucleoside AR agonists and their biological activities, with emphasis on the main derivatives reported in the literature. A focus is also given to the synthetic routes employed to develop these derivatives and on molecular modeling studies simulating their interaction with ARs.
\end{abstract}

Keywords: purinergic receptors; adenosine receptors; adenosine receptor agonists; non-nucleoside agonists; pyridine derivatives; pyrimidine derivatives; ligand-target interaction; drug discovery

\section{Introduction}

The endogenous nucleoside adenosine regulates a number of physiological and pathological processes through the stimulation of membrane proteins named adenosine receptors (ARs). These proteins are $G$ protein-coupled receptors cloned as four subtypes $\left(A_{1}, A_{2 A}, A_{2 B}\right.$, and $\left.A_{3} A R s\right)[1,2]$ and coupled to cytoplasmic GTP-binding proteins that mediate the intracellular effects of AR stimulation. In particular, the stimulation of the $\mathrm{A}_{2 \mathrm{~A}}$ and $\mathrm{A}_{2 \mathrm{~B}}$ ARs leads to an increase of intracellular cAMP levels through activation of a $G$ protein, while the stimulation of the $A_{1}$ and $A_{3}$ ARs leads to a decrease of intracellular cAMP levels through activation of Gi/o proteins. Modulation of further second messengers has also been described, which involves the activation of signaling mechanisms like phospholipase $C$, Protein Kinase C (PKC), phosphoinositide 3-kinases, ion channels, and the modulation of calcium levels $[1,3,4]$. The stimulation of the various AR subtypes has effects on Central Nervous System (CNS) and peripheral tissues [5,6], modulating release of neurotransmitters, synaptic transmission [7], heart rate and atrial contractility, vascular smooth muscle tone [8], gastrointestinal functions $[9,10]$, as well as renal [11], platelet [12], and leukocyte [13] functions. Therefore, AR regulation represents a high-potential strategy for the development of therapeutic tools. On the other hand, widespread AR expression requires compounds endowed not only with high potency and efficacy at the various ARs but also with selectivity for specific AR subtypes [14]. To date, a limited number of adenosinergic ligands have been approved for therapy besides Ado itself, that is, the $\mathrm{A}_{2 \mathrm{~A}} \mathrm{AR}$ agonist Regadenoson 
(approved as a coronary vasodilator) and the $\mathrm{A}_{2 \mathrm{~A}} \mathrm{AR}$ antagonist Istradefylline as an anti-Parkinson drug [15-17].

Several compounds have been designed and developed as AR agonists, where adenosine generally represents the core scaffold further modified to obtain compounds with various degrees of AR potency and selectivity [18]. The key modifications made to the endogenous ligand are at both the purine moiety and the ribose ring. In the first case, substituents introduced at the 2- and $N^{6}$-position lead to an improvement of the affinity/potency and often selectivity for specific AR subtypes, depending on the volume and chemical-physical profile of the substituents themselves. A key modification of the ribose moiety is at its 4 '-position, with the introduction of an $N$-alkylcarboxamido function (the so-called MECA, N-methylcarboxamidoadenosine, or NECA, N-ethylcarboxamidoadenosine, derivatives, where the alkyl group consists of a methyl or an ethyl function, respectively) [19-22]. This modification generally improves the activity at all the AR subtypes with respect to the corresponding adenosine analogues. Conversely, the removal of the ribose moiety or its replacement with a small alkyl group was generally observed as associated to an agonist-to-antagonist switch of the pharmacological profile [23-25].

Recent developments in this field have occurred since the publication of some patents and articles in the early 2000s describing non-nucleoside agonists of the ARs [26-30]. The early data are related to non-selective agonists ranging from partial to full agonist profiles. Subsequent reports described further non-nucleoside derivatives endowed with low nanomolar potency and improved selectivity for the $A_{1}, A_{2 A}$, or $A_{2 B} A R$ subtypes [30-38]. Structural features and biological activity of these molecules, synthetic approaches, and molecular modelling studies simulating the interaction between these compounds and AR targets are reviewed in this work.

\section{Non-Nucleoside Agonists of the ARs}

\subsection{Structural Features and Biological Activity}

\subsubsection{Pyridine Derivatives}

The discovery and development of pyridine-based non-nucleoside agonists of the ARs started from the publication of patents from Bayer describing pyridine derivatives endowed with agonist activity at the ARs $[26-29,39]$. These compounds were generally 2-aminopyridines presenting two cyano groups at the 3- and 5-positions, a phenyl group in the 4-position, and in the 6-position a further substituent starting with a methylthio spacer followed by groups of various volumes and chemical-physical properties. The key structural modifications applied to the series were related to the 6-chain and to further substituents to be inserted to the 4-phenyl ring. These studies led to the discovery of compounds of significative importance, in particular for the $A_{1} A R$. One of these compounds is the $A_{1} A R$ agonist 2-amino-6-[[2-(4-chlorophenyl)-1,3-thiazol-4-yl]methylsulfanyl]-4-[4-(2-hydroxyethoxy)phenyl]pyridine3,5-dicarbonitrile, also named BAY 68-4986 or Capadenoson (1; Figure 1; Table 1). This compound consists in a 2-aminopyridine presenting two cyano groups at the 3- and 5-positions, a substituted phenyl group in the 4-position, and in the 6-position a thiomethyl spacer with a substituted thiazole. Capadenoson currently represents a reference $\mathrm{A}_{1} \mathrm{AR}$ partial agonist, endowed with subnanomolar potency at the human $A_{1} A R$ [39-41]. Capadenoson was shown to dose-dependently modulate the stress-induced heart rate changes and the release of norepinephrine from cardiac presynaptic nerves in the perfused hearts of spontaneously hypertensive rats [42]. In canine models of heart failure, the administration of Capadenoson improved the left ventricular function and prevented progressive remodeling [43]. In a phase II clinical study, Capadenoson was shown to modulate the heart rate in patients with stable angina [44], even if it was later withdrawn [45]. In another phase II clinical study (patients with persistent or permanent atrial fibrillation), this molecule did not show a relevant effect in the modulation of heart rate $[46,47]$. Further clinical evaluations of this molecule were not reported. Capadenoson was also studied as modulator of body temperature in rats, showing a slight hypothermic effect compared to the $\mathrm{A}_{1} \mathrm{AR}$ full agonist $\mathrm{CHA}$ [48]. This molecule also showed 
a favorable DMPK (drug metabolism and pharmacokinetics) profile [39,46] The advantages of the use of partial $A_{1} A R$ agonists were highlighted in one of these works, including the ability of these compounds to not lead to receptor desensitization, the multifaceted set of effects in various tissues where different levels of $\mathrm{A}_{1} \mathrm{AR}$ expression are observed, the lower risk of producing severe side effects with respect to full agonists [46]. A biased agonism of Capadenoson was also assessed since this compound exhibited high potency in the activation of all the intracellular pathways upon $A_{1} A R$ stimulation, with the exception of the intracellular calcium mobilization, where the effect was lower with respect to other $\mathrm{A}_{1} \mathrm{AR}$ reference agonists [49]. Considering the AR affinity, Capadenoson showed also a high $\mathrm{A}_{1} \mathrm{AR}$ selectivity versus the other $\mathrm{AR}$ subtypes where the percentage of radioligand displacement was $0-2.5 \%$ [36]. In contrast, a recent work reported that this molecule can also bind the $\mathrm{A}_{2 \mathrm{~B}} \mathrm{AR}$ with a Ki of about $300 \mathrm{nM}$, but the authors did not specify the affinity at the other subtypes. In the same work, the potency of $\mathbf{1}$ in functional experiments was given as $\mathrm{EC}_{50}$ equal to $0.66 \mathrm{nM}$, $1400 \mathrm{nM}$, and $1.1 \mathrm{nM}$ at the $\mathrm{A}_{1}, \mathrm{~A}_{2 \mathrm{~A}}$, and $\mathrm{A}_{2 \mathrm{~B}} \mathrm{ARs}$, respectively (Table 1) [41].
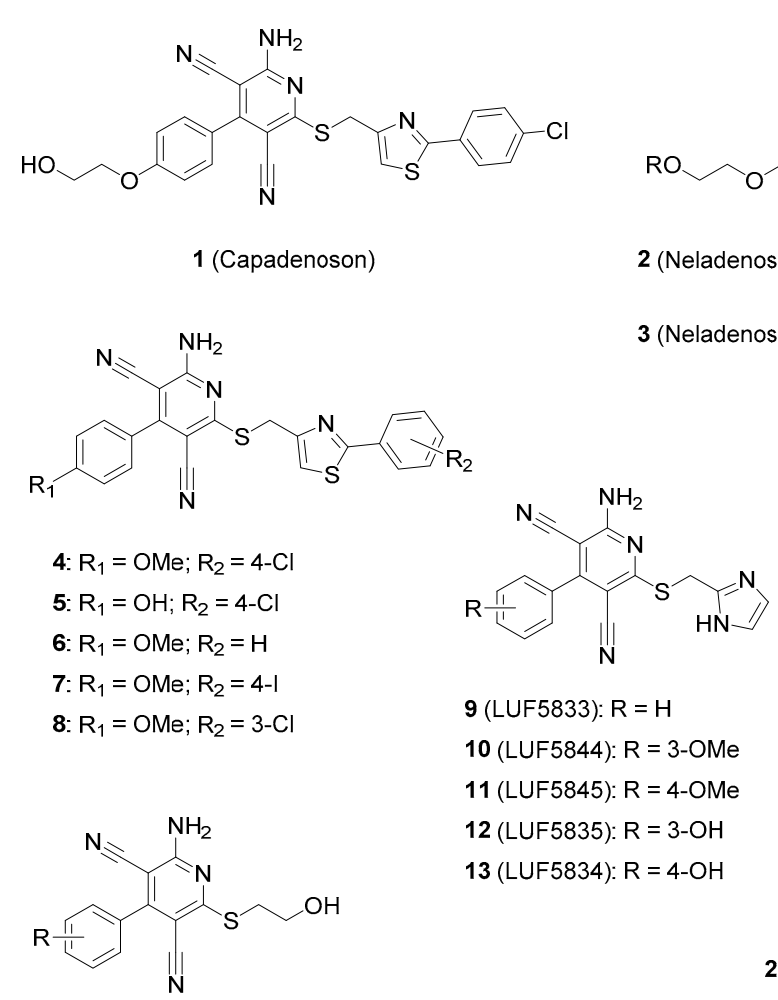

9 (LUF5833): $\mathrm{R}=\mathrm{H}$ 10 (LUF5844): $R=3-O M e$ 11 (LUF5845): $\mathrm{R}=4-\mathrm{OMe}$ 12 (LUF5835): $\mathrm{R}=3-\mathrm{OH}$ 13 (LUF5834): $\mathrm{R}=4-\mathrm{OH}$

2 (Neladenoson): $\mathrm{R}=\mathrm{H}$ 3 (Neladenoson bialanate): $\mathrm{R}=\overbrace{\mathrm{H}} \mathrm{NH}_{2} \cdot \mathrm{HCl}$

15: $\mathrm{R}=\mathrm{H}$

16: $\mathrm{R}=3-\mathrm{OH}$

17 (LUF5831): $\mathrm{R}=4-\mathrm{OH}$

18: $\mathrm{R}=3-\mathrm{OMe}$

19: $\mathrm{R}=4-\mathrm{OMe}$

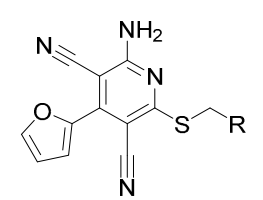

20: $\mathrm{R}=\mathrm{CH}_{2} \mathrm{OH}$

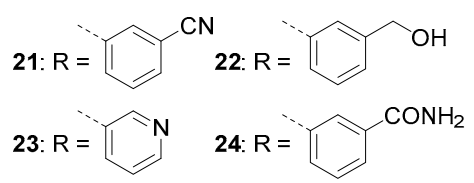<smiles>COc1cccc(-c2c(C#N)c(N)nc(SCc3cccc(C)n3)c2C#N)c1</smiles>

14 (MMPD)

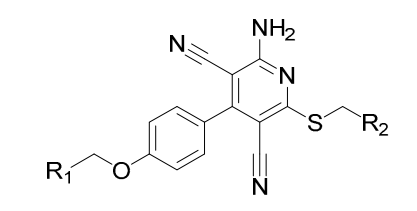

25 (BAY 60-6583): $\mathrm{R}_{1}=\cdots \nabla \mathrm{R}_{2}=\mathrm{CONH}_{2}$

26: $\mathrm{R}_{1}=\mathrm{Me} ; \quad \mathrm{R}_{2}=\mathrm{CONH}_{2}$

27: $R_{1}=\cdots \nabla R_{2}=\cdots{ }^{C O N H}$

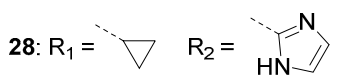

29: $R_{1}=\cdots \nabla \quad R_{2}=\stackrel{\cdots}{\cdots N}=N$

30: $R_{1}=M e \quad R_{2}=\stackrel{H N}{C N}$

Figure 1. Selected pyridine-based non-nucleoside agonists of the adenosine receptors.

Interestingly, Capadenoson showed a biased agonism also at the $\mathrm{A}_{2 \mathrm{~B}} \mathrm{AR}$ since it activated the cAMP pathway with higher potency with respect to the other pathways induced by $\mathrm{A}_{2 \mathrm{~B}} \mathrm{AR}$ stimulation. Structural modifications at the exocyclic amine group of Capadenoson led to the development 
of the $\mathrm{A}_{1} \mathrm{AR}$ agonist 2-((2-(4-chlorophenyl)-1,3-thiazol-4-ylmethyl)sulfanyl)-4-(4-(2-hydroxyethoxy) phenyl)-6-(pyrrolidin-1-yl)pyridine-3,5-dicarbonitrile, also named Neladenoson (2; Figure 1; Table 1). Like Capadenoson, Neladenoson is a selective partial agonists of the $A_{1} A R$ [50,51]. Neladenoson showed cardioprotective effects in rat preclinical models, analogously to Capadenoson, although with lower central effects. A bialanate (alanine-alanine ester) derivative of Neladenoson (in its hydrochloride salt form) was also developed as a prodrug, showing a more favorable pharmacokinetic profile.

Neladenoson bialanate (BAY 1067197; 3; Figure 1) is currently in clinical evaluation for the treatment of chronic heart failure with preserved/reduced ejection fraction (HFpEF and HFrEF, respectively) [50-57]. Early results show a lack of dose-dependent favorable effects on cardiac structure and function and on exercise capacity, with a dose-dependent decrease in renal function [58,59].

Further derivatives of Capadenoson were developed, with the evaluation of their binding affinity and dissociation kinetics properties at the $\mathrm{A}_{1} \mathrm{AR}$ (as examples are reported compounds 4-8; Figure 1; Table 1). Several of these derivatives were endowed with good $A_{1} A R$ affinity and selectivity, ranging from partial to full agonist profiles [36]. In particular, considering the modifications on the 4-phenyl ring of Capadenoson, the replacement of the para-hydroxyethyloxy substituent with a hydroxy group maintain the $\mathrm{A}_{1} \mathrm{AR}$ affinity of Capadenoson $\left(5, \mathrm{Ki} \mathrm{A} \mathrm{AR}_{1}=1.5 \mathrm{nM}\right.$, versus $1, \mathrm{Ki} \mathrm{A}_{1} \mathrm{AR}=1.4 \mathrm{nM}$; Table 1 ). The replacement of the same moiety with a methoxy group (4) led to the synthesis of a Capadenoson analogue that was further modified at the phenyl group present in the 2-position of the thiazole ring. In this set of derivatives, high $\mathrm{A}_{1} \mathrm{AR}$ affinities were obtained with compounds presenting a phenyl ring substituted in the para-position with a halogen atom (i.e., 7). In some cases, compounds were found endowed with residence times up to $132 \mathrm{~min}$ (4), about 4.7-fold longer than Capadenoson itself [36].

A work by Beukers and colleagues [31] described five 2-aminopyridines derivatives with similarities to Capadenoson, given the presence of two cyano groups at the 3- and 5-positions and a phenyl group in the 4-position. In the 6-position, a thiomethyl spacer with a 2-imidazole ring was inserted. The 4-phenyl group could be further substituted with a hydroxy or methoxy group in the paraor meta-position. Results of biological evaluation of these compounds showed a low nanomolar affinity for the $A_{1}$ but also for the $A_{2 B}$ ARs (9-13; Figure 1; Table 1). The most potent $A_{1}$ and $A_{2 B}$ AR agonists of this group (then named LUF5844, 10, and LUF5845, 11, respectively) present a methoxy group in the meta- or para-position 4-phenyl ring, respectively. A modification of LUF5844 by substituting the imidazole ring with a 6-methylpyridin-2-yl group led to the development of the compound 2-amino-4-(3-methoxyphenyl)-6-(2-(6-methylpyridin-2-yl)ethyl)pyridine-3,5-dicarbo- nitrile (MMPD; 14; Figure 1; Table 1), a partial $A_{1} A R$ agonist endowed with subnanomolar affinity for this receptor and high selectivity versus the other AR subtypes. This compound was also developed as a radioligand useful for Positron Emission Tomography (PET) imaging in the brain, given its good pharmacokinetics profile related to the ability to cross the Blood Brain Barrier (BBB) $[60,61]$. Even the compound 2-amino-4-(4-hydroxy phenyl)-6-(1H-imidazol-2ylmethylsulfanyl)-pyridine-3,5-dicarbonitrile [31], then named LUF5834 (13; Figure 1; Table 1), was developed as a radioligand able to bind to $\mathrm{A}_{1} \mathrm{AR}$ in both G-protein-coupled and uncoupled conditions with a similar high affinity [34]. Since this molecule showed nanomolar affinity also for the $\mathrm{A}_{2 \mathrm{~A}} \mathrm{AR}$, it was employed for a mutagenesis study at this $\mathrm{AR}$ subtype, in comparison with the nucleoside derivative CGS21680. Results showed that the potencies of LUF5834 and CGS21680 are differently subjected to variations due to mutations of binding site residues, suggesting different ligand-receptor interactions between nucleoside and non-nucleoside agonists and the $A_{2 A} A R$ [37]. The same research group later reported the synthesis and biological evaluation of 9-13 analogues where the imidazolyl-methyl-thio substituent in the 6-position was replaced by a hydroxy-ethyl-thio group [32]. In general, these compounds, (15-19; Figure 1; Table 1), showed $A_{1} A R$ selectivity, with affinity in the nanomolar range. Low nanomolar or subnanomolar potencies of some of these compounds at the $\mathrm{A}_{1} \mathrm{AR}$ were also reported by Bayer researchers [39]. Interestingly, some of these derivatives showed full agonist activity at the $\mathrm{A}_{1} \mathrm{AR}$, while other similar derivatives proved to be inverse agonists of the same receptor. The presence of a small substituent in the meta-position of the 4-phenyl ring generally appeared more important with respect to the insertion of the same 
group in the para-position for the $\mathrm{A}_{1} \mathrm{AR}$ affinity and for both agonist and antagonist/inverse agonist activities [32]. One of these compounds, named LUF5831 (17; Figure 1; Table 1), initially showed almost full agonist activity at the $\mathrm{A}_{1} \mathrm{AR}$. In a subsequent work [33], the $\mathrm{A}_{1} \mathrm{AR}$ partial agonist profile of the same compound was reported. Interestingly, the same molecule appeared to maintain the affinity for a mutated $A_{1} A R$ (T277A) differently from the nucleoside agonist cyclopentyladenosine (CPA) that lost its binding ability to the mutated receptor. Furthermore, the affinity of LUF5831 for the A AR was reduced by the presence of the allosteric modulator PD81,723, which conversely led to an improvement of the $\mathrm{A}_{1} \mathrm{AR}$ affinity of the nucleoside agonist CPA [33].

Table 1. Binding affinity $\left(\mathrm{K}_{\mathrm{i}}\right)$ and potency $\left(\mathrm{EC}_{50}\right)$ data of selected pyridine-based non-nucleoside agonists of the ARs.

\begin{tabular}{|c|c|c|c|c|c|c|c|}
\hline \multirow[t]{2}{*}{ Compound } & \multicolumn{4}{|c|}{ Affinity Data ( $\mathrm{K}_{\mathrm{i}} \mathrm{nM}$, or \% Radioligand Displ.) } & \multicolumn{3}{|c|}{ Potency Data $\left(\mathrm{EC}_{50} \mathrm{nM}\right)$} \\
\hline & $\mathbf{A}_{1} \mathrm{AR}$ & $\mathrm{A}_{2 \mathrm{~A}} \mathrm{AR}$ & $\mathrm{A}_{2 \mathrm{~B}} \mathrm{AR}$ & $\mathrm{A}_{3} \mathrm{AR}$ & $\mathbf{A}_{1} \mathrm{AR}$ & $\mathrm{A}_{2 \mathrm{~A}} \mathrm{AR}$ & $\mathrm{A}_{2 \mathrm{~B}} \mathrm{AR}$ \\
\hline $1[36,41]$ & $1.4^{\mathrm{a}, \mathrm{d}}$ & $0 \% \mathrm{~b}, \mathrm{e}$ & $2.5 \% \mathrm{a}, \mathrm{f}$ & $1.2 \%$ a,g & $0.66^{c}$ & $1400^{c}$ & $1.1^{\mathrm{C}}$ \\
\hline $2[50]$ & - & - & - & - & $0.1^{\mathrm{a}}$ & $670^{a}$ & $80^{\mathrm{a}}$ \\
\hline $4[36]$ & $5.0^{\mathrm{a}, \mathrm{d}}$ & $5.8 \% \mathrm{~b}, \mathrm{e}$ & $20 \%$ a,f & $19 \%$ a,g & $2.9^{\mathrm{a}}$ & - & - \\
\hline $5[36]$ & $1.5^{\mathrm{a}, \mathrm{d}}$ & - & - & - & - & - & - \\
\hline $6[36]$ & $8.4^{\mathrm{a}, \mathrm{d}}$ & $0.0 \% \mathrm{~b}, \mathrm{e}$ & $63 \%$ a,f & $27 \%$ a,g & $1.9^{a}$ & - & - \\
\hline 7 [36] & $3.9^{\mathrm{a}, \mathrm{d}}$ & - & - & - & - & - & - \\
\hline $8[36]$ & $12^{a, d}$ & - & - & - & - & - & - \\
\hline 9 [31] & $2.4^{\mathrm{a}, \mathrm{d}}$ & $28^{b, e}$ & - & $171^{\mathrm{b}, \mathrm{h}}$ & - & - & $19^{a}$ \\
\hline 10 [31] & $2.0^{\mathrm{a}, \mathrm{d}}$ & $105^{b, e}$ & - & $74^{b, h}$ & - & - & $34^{\mathrm{a}}$ \\
\hline 11 [31] & $7.0^{\mathrm{a}, \mathrm{d}}$ & $214^{b, e}$ & - & $24^{b, h}$ & - & - & $9^{a}$ \\
\hline 12 [31] & $4.4^{\mathrm{a}, \mathrm{d}}$ & $21^{b, e}$ & - & $104^{b, h}$ & - & - & $10^{a}$ \\
\hline $\mathbf{1 3}[31,37]$ & $2.6^{\mathrm{a}, \mathrm{d}}$ & $28^{b, e}$ & - & $538^{b, h}$ & $3.29^{a}$ & $16.2^{b}$ & $12^{a}$ \\
\hline 14 [60] & $0.49^{b, d}$ & $71^{b, e}$ & $75^{b, i}$ & $42 \%$ b,h & $1.0^{b}$ & - & - \\
\hline $15[32,39]$ & $15^{a, d}$ & $23 \%$ a,e & - & $26 \%$ b,h & $0.7^{\mathrm{a}}$ & $>3000^{a}$ & $670^{a}$ \\
\hline 16 [32] & $12^{\mathrm{a}, \mathrm{d}}$ & $25 \%$ a,e & - & $16 \%$ b,h & - & - & - \\
\hline $\mathbf{1 7}[32,39]$ & $23^{a, d}$ & $37 \%$ a,e & - & $0 \%$ b,h & $0.5^{\mathrm{a}}$ & $>3000^{a}$ & $248^{a}$ \\
\hline 18 [32] & $4.3^{\mathrm{a}, \mathrm{d}}$ & $21 \%$ a,e & - & $18 \%$ b,h & - & - & - \\
\hline $19[32,39]$ & $41^{\mathrm{a}, \mathrm{d}}$ & $8 \%$ a,e & - & $21 \% b, h$ & $2.7^{a}$ & $>3000^{a}$ & $>3000^{a}$ \\
\hline 20 [62] & $57^{a, d}$ & $27 \%$ a,e & - & $29 \%$ a,h & - & - & $>1000^{a}$ \\
\hline 21 [62] & $1.02^{\mathrm{a}, \mathrm{d}}$ & $93^{a, e}$ & - & $668^{a, h}$ & - & - & $>1000^{a}$ \\
\hline 22 [62] & $0.98^{a, d}$ & $31^{\mathrm{a}, \mathrm{e}}$ & - & $25 \%$ a,h & - & - & $>1000^{a}$ \\
\hline 23 [62] & $1.42^{\mathrm{a}, \mathrm{d}}$ & $24^{\mathrm{a}, \mathrm{e}}$ & - & $948^{a, h}$ & - & - & $>1000^{a}$ \\
\hline 24 [62] & $1.32^{\mathrm{a}, \mathrm{d}}$ & $67^{a, e}$ & - & $326^{a, h}$ & - & - & $>1000^{\mathrm{a}}$ \\
\hline $25[39,63,64]$ & $31 \%$ a,d & $2 \% a, e$ & $114^{\mathrm{a}, \mathrm{f}}$ & $8 \%$ a,h & - & - & $10^{a}$ \\
\hline 26 [64] & $345^{\mathrm{a}, \mathrm{d}}$ & $1 \%{ }^{a, e}$ & - & $20 \%$ a,h & - & - & $38^{a}$ \\
\hline 27 [64] & $83^{\mathrm{a}, \mathrm{d}}$ & $25 \%$ a,e & - & $1 \%$ a,h & - & - & $12.7^{a}$ \\
\hline 28 [64] & $235^{a, d}$ & $764^{\mathrm{a}, \mathrm{e}}$ & - & $474^{\mathrm{a}, \mathrm{h}}$ & - & - & $9.5^{\mathrm{a}}$ \\
\hline 29 [64] & $338^{a, d}$ & $1 \%{ }^{a, e}$ & - & $1 \%{ }^{a, h}$ & - & - & $51^{a}$ \\
\hline 30 [64] & $8.2^{\mathrm{a}, \mathrm{d}}$ & $221^{\mathrm{a}, \mathrm{e}}$ & - & $85^{a, h}$ & - & - & $11.7^{\mathrm{a}}$ \\
\hline
\end{tabular}

(a) human AR subtype stably expressed by CHO (Chinese hamster ovary) cells; $\left({ }^{b}\right)$ human AR subtype stably expressed by HEK (human embryonic kidney) 293 cells; $\left(^{(}\right)$human AR subtype stably expressed by FlpIn-CHO cells; ( $\left.{ }^{\mathrm{d}}\right)$ displacement of $\left[{ }^{3} \mathrm{H}\right] \mathrm{DPCPX}$ as radioligand; $\left({ }^{\mathrm{e}}\right)$ displacement of $\left[{ }^{3} \mathrm{H}\right] \mathrm{ZM} 241385$ as radioligand; $\left({ }^{\mathrm{f}}\right)$ displacement of $\left[{ }^{3} \mathrm{H}\right]$ PSB603 as radioligand; $\left({ }^{\mathrm{g}}\right)$ displacement of $\left[{ }^{3} \mathrm{H}\right] \mathrm{PSB} 11$ as radioligand; $\left({ }^{\mathrm{h}}\right)$ displacement of $\left[{ }^{125} \mathrm{I}\right] \mathrm{I}-\mathrm{ABMECA}$ as radioligand; $\left({ }^{\mathrm{i}}\right)$ displacement of $\left[{ }^{3} \mathrm{H}\right] \mathrm{NECA}$ as radioligand. For complete experimental details, please refer to the indicated references. 
This suggested that the interaction between the non-nucleoside agonist LUF5831 and the receptor could involve some residues different with respect to the ones interacting with the nucleoside derivative $\mathrm{CPA}$, as later suggested also at the $\mathrm{A}_{2 \mathrm{~A}} \mathrm{AR}$ (see above LUF5834) [37].

Further 2-amino-3,5-dicyanopyridines were recently reported, bearing a 2-furyl ring in the 4-position and a thiomethyl chain in the 6-position, further substituted with groups of various volumes, polarity, and chemical-physical properties. Interestingly, all these compounds showed antagonist activity at the $A_{1} A R$, with affinity data in the low nanomolar range in several cases (as examples are reported compounds 20-24; Figure 1; Table 1). The replacement of the 4-phenyl ring with a 2-furyl group seems critical for the agonist-to-antagonist shift in the intrinsic activity of the compounds [62].

Among the pyridine derivatives acting as agonists at the ARs, a key compound is BAY 60-6583 (25; Figure 1; Table 1). This molecule was introduced as a selective $A_{2 B} A R$ agonist, with $E_{50}$ potency data at a low nanomolar level $[39,65,66]$. Various affinity/potency data were then reported for this molecule at the same receptor, in all cases ranging in the nanomolar/submicromolar level $[39,63,64,67,68]$. These observed variations of affinity or potency may be due to different assay protocols or conditions. Considering the molecular structure, the 3,5-dicyano-6-aminopyridine nucleus is still present, with the introduction of a substituted phenyl ring in the 4-position and a thioacetamide chain in the 2-position. This molecule soon became a reference ligand for pharmacological studies involving the $A_{2 B} A R$, given the low availability of selective ligands for this receptor. In a mutagenesis study at the $A_{2 B} A R$, the potency and efficacy of BAY 60-6583 was tested at various receptor mutants, in comparison to the nucleoside agonist NECA [68]. Results showed that in some cases, the mutations led to different effects for non-nucleoside and nucleoside agonists, considering both the potency ( $\mathrm{EC}_{50}$ data) and efficacy as full or partial agonist, in agreement to what was observed at the $A_{1} A R$ [33] and $A_{2 A} A R$ [37]. The partial agonist profile of this molecule at the $A_{2 B} A R$ was then assessed [69], even if the results of the study suggested the authors to highlight that the intrinsic activity of this molecule could vary from full agonist to antagonist depending on the tissue, the receptor expression level, and the local adenosine concentration. BAY 60-6583 was used for several pharmacological studies, analyzing in particular its cardioprotective effects [70,71]. Beneficial effects of this molecule for obesity [72], lung injury [73], and insulin resistance [74,75] were also reported. Though this molecule never entered in clinical trials, analogues of BAY 60-6583 were synthesized and tested [64]. These derivatives differed from BAY 60-6583 in terms of the substituent on the 4-phenyl ring or the 2-chain (as examples are reported compounds 26-30; Figure 1; Table 1). Interestingly, one of these compounds (28), bearing a cyclopropylmethyloxy group in the para-position of the 4-phenyl ring (like BAY 60-6583) and a 2-imidazolyl-methyl-thio chain in the 2-position, showed low nanomolar potency in functional assay at the $\mathrm{A}_{2 \mathrm{~B}} \mathrm{AR}$ together with high nanomolar affinity in binding experiments and seems to show an interesting selectivity versus the other AR subtypes. This selectivity is higher compared to analogues bearing the same 2-substituent and presenting in the 4-position a phenyl ring unsubstituted or substituted by smaller groups (9-13; Figure 1; Table 1) [31]. Further derivatives of this work showed $\mathrm{A}_{2 \mathrm{~B}} \mathrm{AR}$ potency within the nanomolar range, although in some cases with limited selectivity.

\subsubsection{Pyrimidine Derivatives}

The pyrimidine scaffold was used as a core structure for the development of AR ligands generally endowed with antagonist activity and, in some cases, low nanomolar affinity [76]. These compounds were 2,6-diphenylpyrimidine or 4,6-diphenylpyrimidine derivatives bearing a substituted amide function in the 4- or 2-position, respectively. The second group showed a marked selectivity for the $\mathrm{A}_{1} \mathrm{AR}$. Further development of these compounds, obtained by mixing their structural features with the ones of the already described cyanopyridine agonists (see above [31,32]), led to the synthesis of pyrimidine derivatives endowed with inverse agonist activity at the same receptor [77]. The combination of two aromatic rings in the 4- and 5-position of pyrimidine led to the development of an $\mathrm{A}_{2 \mathrm{~B}} \mathrm{AR}$ antagonist [78]. A few years later, with respect to the publication of the early patents on pyridine 
derivatives, two patents about cyanopyrimidine derivatives as $\mathrm{A}_{2 \mathrm{~A}} \mathrm{AR}$ agonists were reported by Otsuka Pharmaceuticals $[30,38]$.

These molecules were 4-amino-6-aryl-5-cyano-2-thiopyrimidines, presenting an acetylamino group in the para-position of the 6-phenyl ring and various substituents within the 2-chain (as examples are reported compounds 31-36; Figure 2; Table 2). These compounds present several similarities compared to the above-described cyanopyridine agonists, with the main difference consisting in the absence of one cyano group of the pyridines substituted by a nitrogen atom in the aromatic scaffold. Several of these compounds were claimed as being endowed with low nanomolar potency at the $A_{2 A} A R$.
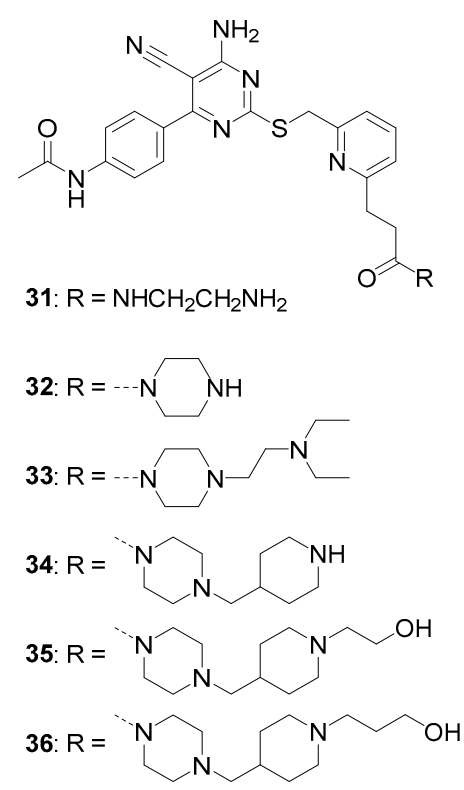

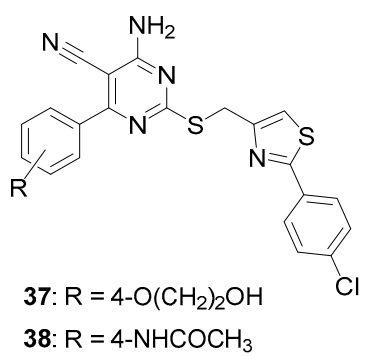

38: $\mathrm{R}=4-\mathrm{NHCOCH}_{3}$

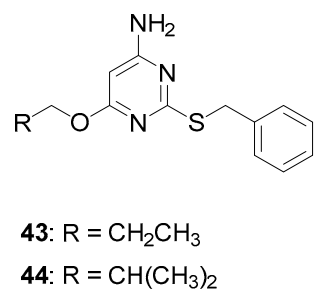

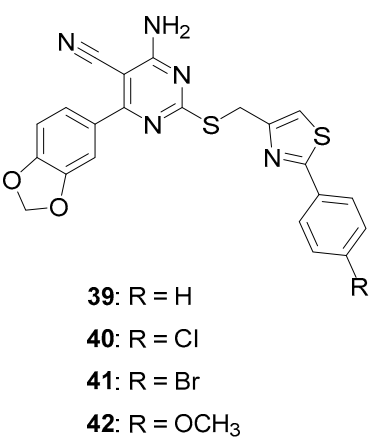

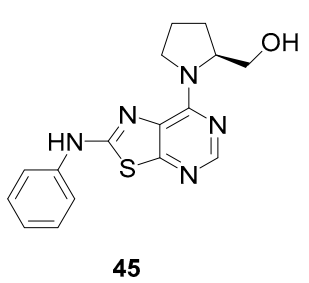

Figure 2. Selected pyrimidine-based non-nucleoside agonists of the adenosine receptors.

In a subsequent work, Louvel and coworkers [35] described cyanopyrimidine obtained by combining structural features of Capadenoson with the pyrimide core. These molecules showed $\mathrm{A}_{1} \mathrm{AR}$ affinity at a low nanomolar level and a good selectivity for the same receptor, with generally a partial agonist profile (as examples are reported compounds 37-42; Figure 2; Table 2). High $A_{1} A R$ affinities were obtained in particular with compounds bearing a 3,4-methylenedioxy substituent on the 4-phenyl ring and a substituted phenyl ring linked to the thiazole moiety of the 2-substituent, with some analogies with respect to what was observed in a study on pyridine-based Capadenoson analogues [36]. In addition, dissociation kinetics were analyzed and reported for the same compounds.

Pyrimidine analogues bearing a 2-thioarylalkyl chain and an alkyloxy group in the 6-position were developed as AR ligands. These compounds (lacking the 5-cyano group and an aromatic ring within the 6-substituent) showed antagonist activity at the ARs [79]. In a successive work, the same authors tested analogues of these molecules based on a pyrimidine scaffold, with the presence of a phenylmethyloxy chain in the 6-position [80]. Biological evaluation of these compounds showed that they are endowed with micromolar affinity for the $\mathrm{A}_{1} \mathrm{AR}$ and high nanomolar agonist potency at the same AR subtype (43-44; Figure 2; Table 2). This suggested the importance of the presence of the 5-cyano group and an aromatic ring directly linked to the heterocyclic core to achieve nanomolar affinity at ARs. The pyrimidine core was also fused with a thiazole moiety to obtain thiazolo[5,4-d]pyrimidine agonists of the $\mathrm{A}_{2 \mathrm{~A}} \mathrm{AR}$. These compounds mimicked some structural features of adenosine, since the 6-substituent inserted in the bicyclic core of the thiazolopyrimidines appears to provide analogue interaction with the receptor cavity with respect to the adenosine ribose ring, according to molecular modelling studies [81]. Results of the biological evaluation of these compounds showed high nanomolar $\mathrm{A}_{2 \mathrm{~A}} \mathrm{AR}$ affinity and moderate selectivity for some derivatives, with a partial agonist profile (as example 45; Figure 2; Table 2). 
Table 2. Binding affinity $\left(\mathrm{K}_{\mathrm{i}}\right)$ and potency $\left(\mathrm{EC}_{50}\right)$ data of selected pyrimidine-based non-nucleoside agonists of the ARs.

\begin{tabular}{|c|c|c|c|c|c|c|c|}
\hline \multirow[t]{2}{*}{ Cpd } & \multicolumn{4}{|c|}{ Affinity Data (K $K_{\mathbf{i}} \mathbf{n M}$, or \% Radioligand Displacement) } & \multicolumn{3}{|c|}{ Potency Data $\left(\mathrm{EC}_{50} \mathrm{nM}\right)$} \\
\hline & $\mathrm{A}_{1} \mathrm{AR}$ & $\mathrm{A}_{2 \mathrm{~A}} \mathrm{AR}$ & $\mathrm{A}_{2 \mathrm{~B}} \mathrm{AR}$ & $\mathrm{A}_{3} \mathrm{AR}$ & $\mathrm{A}_{1} \mathrm{AR}$ & $\mathrm{A}_{2 \mathrm{~A}} \mathrm{AR}$ & $\mathrm{A}_{2 \mathrm{~B}} \mathrm{AR}$ \\
\hline $31[30,38]$ & - & - & - & - & - & $2.8^{\mathrm{b}}$ & - \\
\hline $32[30,38]$ & - & - & - & - & - & $2.5^{\mathrm{b}}$ & - \\
\hline $33[30,38]$ & - & - & - & - & - & $3.0^{b}$ & - \\
\hline $34[30,38]$ & - & - & - & - & - & $3.3^{b}$ & - \\
\hline $35[30,38]$ & - & - & - & - & - & $2.9^{b}$ & - \\
\hline $36[30,38]$ & - & - & - & - & - & $1.8^{b}$ & - \\
\hline 37 [35] & $4.8^{\mathrm{a}, \mathrm{c}}$ & $10 \% \mathrm{~b}, \mathrm{~d}$ & $3.5 \%$ a,e & $3.0 \% \mathrm{a}, \mathrm{f}$ & $12^{\mathrm{a}}$ & - & - \\
\hline 38 [35] & $14^{a, c}$ & $44 \% \mathrm{~b}, \mathrm{~d}$ & $2.5 \%$ a,e & $5.5 \%$ a,f & $3.9^{a}$ & - & - \\
\hline 39 [35] & $2.4^{\mathrm{a}, \mathrm{c}}$ & $-2.0 \% \mathrm{~b}, \mathrm{~d}$ & $20 \%$ a,e & $24 \%$ a,f & $4.6^{a}$ & - & - \\
\hline 40 [35] & $14^{a, c}$ & $4.5 \% \mathrm{~b}, \mathrm{~d}$ & $0 \% \mathrm{a}, \mathrm{e}$ & $4.5 \%$ a,f & $4.9^{a}$ & - & - \\
\hline 41 [35] & $5.2^{\mathrm{a}, \mathrm{c}}$ & $2.9 \% \mathrm{~b}, \mathrm{~d}$ & $1.7 \% \mathrm{o}^{\mathrm{a}, \mathrm{e}}$ & $-1.8 \% \mathrm{a}, \mathrm{f}$ & $4.6^{\mathrm{a}}$ & - & - \\
\hline 42 [35] & $1.8^{\mathrm{a}, \mathrm{c}}$ & $3.2^{b, d}$ & $3.5^{\mathrm{a}, \mathrm{e}}$ & $11^{\mathrm{a}, \mathrm{f}}$ & $1.9^{\mathrm{a}}$ & - & - \\
\hline 43 [80] & $1240^{a, c}$ & $>10,000^{a, g}$ & - & $>10,000^{a, g}$ & $490^{\mathrm{a}}$ & - & Inactive $^{a}$ \\
\hline $44[80]$ & $1945^{a, c}$ & $>10,000^{a, g}$ & - & $>10,000^{a, g}$ & $870^{a}$ & - & Inactive $^{a}$ \\
\hline 45 [81] & $555^{\mathrm{a}, \mathrm{h}}$ & $200^{a, g}$ & - & $978^{a, i}$ & - & - & - \\
\hline
\end{tabular}

${ }^{(a)}$ human AR subtype stably expressed by CHO cells; $\left({ }^{b}\right)$ human AR subtype stably expressed by HEK 293 cells; ( $\left.{ }^{\mathrm{c}}\right)$ displacement of $\left[{ }^{3} \mathrm{H}\right] \mathrm{DPCPX}$ as radioligand; $\left({ }^{\mathrm{d}}\right)$ displacement of $\left[{ }^{3} \mathrm{H}\right] \mathrm{ZM} 241385$ as radioligand; $\left({ }^{\mathrm{e}}\right)$ displacement of $\left[{ }^{3} \mathrm{H}\right] \mathrm{PSB} 603$ as radioligand; $\left({ }^{\mathrm{f}}\right)$ displacement of $\left[{ }^{3} \mathrm{H}\right] \mathrm{PSB} 11$ as radioligand; $\left({ }^{\mathrm{g}}\right)$ displacement of $\left[{ }^{3} \mathrm{H}\right] \mathrm{NECA}$ as radioligand; $\left({ }^{\mathrm{h}}\right)$ displacement of $\left[{ }^{3} \mathrm{H}\right] \mathrm{CCPA}$ as radioligand; $\left({ }^{\mathrm{i}}\right)$ displacement of $\left[{ }^{3} \mathrm{H}\right] \mathrm{HEMADO}$ as radioligand. For complete experimental details, please refer to the indicated references.

\subsection{Synthetic Approaches}

As reported above, two main scaffolds of compounds with non-nucleosidic structure and agonist properties for ARs have been identified.

The first series of compounds were substituted 3,5-dicarbonitrile pyridine. Their synthesis and biological evaluation were reported in two patents by Bayer [26,27]. The synthetic procedure involved the reaction of an aldehyde with malononitrile in basic conditions to give the aryilidenemalononitrile, which reacted with another molecule of malononitrile and, in the presence of thiophenol, furnished the 2-amino-4-aryl-6-(phenylthio)pyridine-3,5-dicarbonitriles (general structure I). The latter compound was used for the production of the useful intermediate 6-thiol derivative II by elimination of the phenyl group with sodium sulfide and then treatment with chloridric acid to get the thiol derivative. The reaction of II with the suitable alkylhalide chains furnished the desired final 3,5-dicarbonitrile pyridines III (Scheme 1).
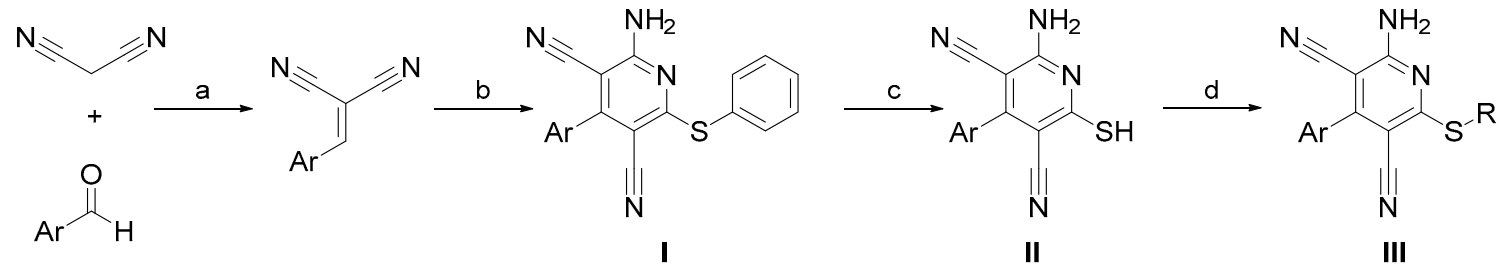

Scheme 1. Synthetic route to obtain the 3,5-dicarbonitrile pyridines. Reagents and conditions: (a) piperidine, $\mathrm{EtOH}$; (b) malononitrile, thiophenol, $\mathrm{Et}_{3} \mathrm{~N}, \mathrm{EtOH}$; (c) (i) $\mathrm{Na}_{2} \mathrm{~S}, \mathrm{DMF}$, (ii) $1 \mathrm{M} \mathrm{HCl}$; (d) alkylhalide, $\mathrm{NaHCO}_{3}, \mathrm{DMF}$; $\mathrm{Ar}=$ aryl, $\mathrm{R}=$ alkyl. 
The reaction pathway for the production of such a series of compounds was previously reported by other authors [82-84]. In particular Dyachenko and Litvinov obtained the 6-amino-3,5dicyanopyridine-2(1H)-thione derivatives IIIa from ethyl 3-(4-butoxyphenyl)-2-cyanoacrylate or 4-butoxy benzaldehyde and cyanothioacetamide in basic conditions by $\mathrm{N}$-methylmorpholine with the reaction mechanism suggested, as depicted in Figure 3 [85].

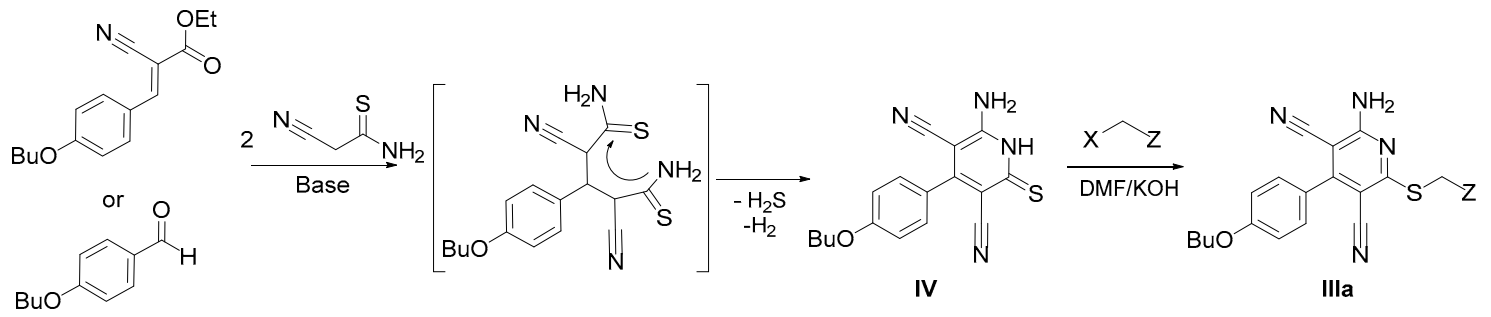

Figure 3. Mechanism proposed by Dychenko and Litvinov for the cyclization formation of 3,5-dicyano pyridine derivatives. $\mathrm{X}=\mathrm{Br}, \mathrm{Cl} ; \mathrm{Z}=4-\mathrm{Cl}-\mathrm{Ph}, \mathrm{CH}_{3} \mathrm{COO}$, $\mathrm{PhCO}, \mathrm{CH}_{2}=\mathrm{CH}, \mathrm{NH}_{2} \mathrm{CO}, \mathrm{H}, 4-\mathrm{Br}-\mathrm{PhCO}$, 4-Cl-PhCO, EtCOO, $\mathrm{PhCH}_{2} \mathrm{COO}$, 2-oxo-3-pyrazynylcarbonyl, $\mathrm{PhNHCO}, \mathrm{CN} ; \mathrm{B}=\mathrm{N}$-methylmorpholine.

Subsequently, on the basis of data previously published in the patent from Bayer, Beukers and coworkers evaluated some 3,5-dicarbonitrile derivatives as human $A_{2 B}$ adenosine receptor agonists, which were synthesized with the previously reported procedure [31]. Both the synthetic approaches used the thiol intermediate that was reacted with the suitable organic halide to obtain the final 2-thioalkylpyridine derivatives.

A different methodology was used by Evdokimov and colleagues, who prepared a series of 2-amino-3,5-dicyano-6-sulfanylpyridines and 1,4-dihydropyridines via a single-step, three-component reaction of malononitrile with different aldehydes and thiols (Scheme 2) [86].
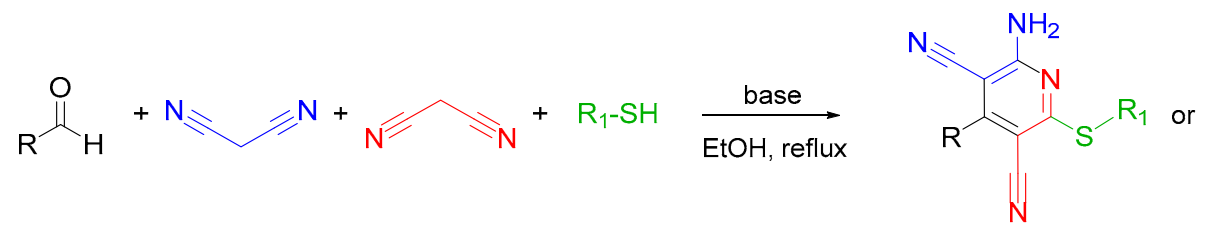<smiles></smiles>

Scheme 2. Synthesis of the 2-amino-3,5-dicyano-6-sulfanylpyridines via the single-step, three-component reaction.

The hypothesized mechanism of the reaction includes the formation of 1,4-dihydropyridines, which undergo oxidation by the Knoevenagel adducts rather than air oxygen (Figure 4). As base, 1,4-diazabicyclo[2.2.2]octane (DABCO) or trimethylamine was used and 2-amino-3,5-dicarbonitrile6-thio-pyridine derivatives in $20-48 \%$ yields were obtained due to the formation of 1,4-dihydropyridines as side products.

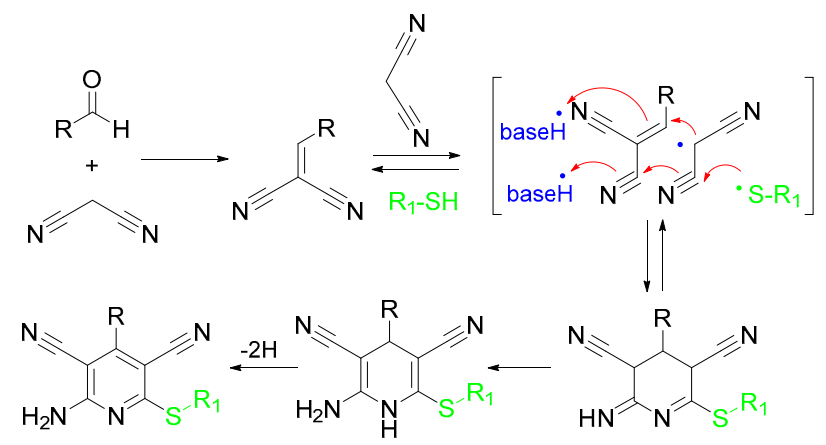

Figure 4. Reaction mechanism of the single-step, three-component reaction formulated by Evdokimov. 
Due to the importance such a class of molecules has acquired over the time, several other synthetic routes have been attempted. In particular, in one of them are reported conditions that led to the use of less pollutant reagent/catalyst/waste or better yields using a different catalytic agent.

Sridhar and co-workers [87] firstly reported the application of Lewis acids as catalysts in the preparation of this class of compounds using the single-step approach to react the suitable aldehyde with malononitrile and thiophenol. Furthermore, a comparison of conventional or microwave heating to obtain the 2-amino-3,5-dicarbonitrile-6-(phenylthio)pyridine-4-substituted intermediates was described. The substitution of the base catalysis with the Lewis acid led to a doubling of the yield of the reaction when $\mathrm{ZnCl}_{2}$ was used as Lewis acid (Figure 5). Comparing the two methods, it is possible to assume that there was not an increment of the yield with the microwave protocol, but in this case, a few minutes of heating was sufficient to obtain the final product with good yield.

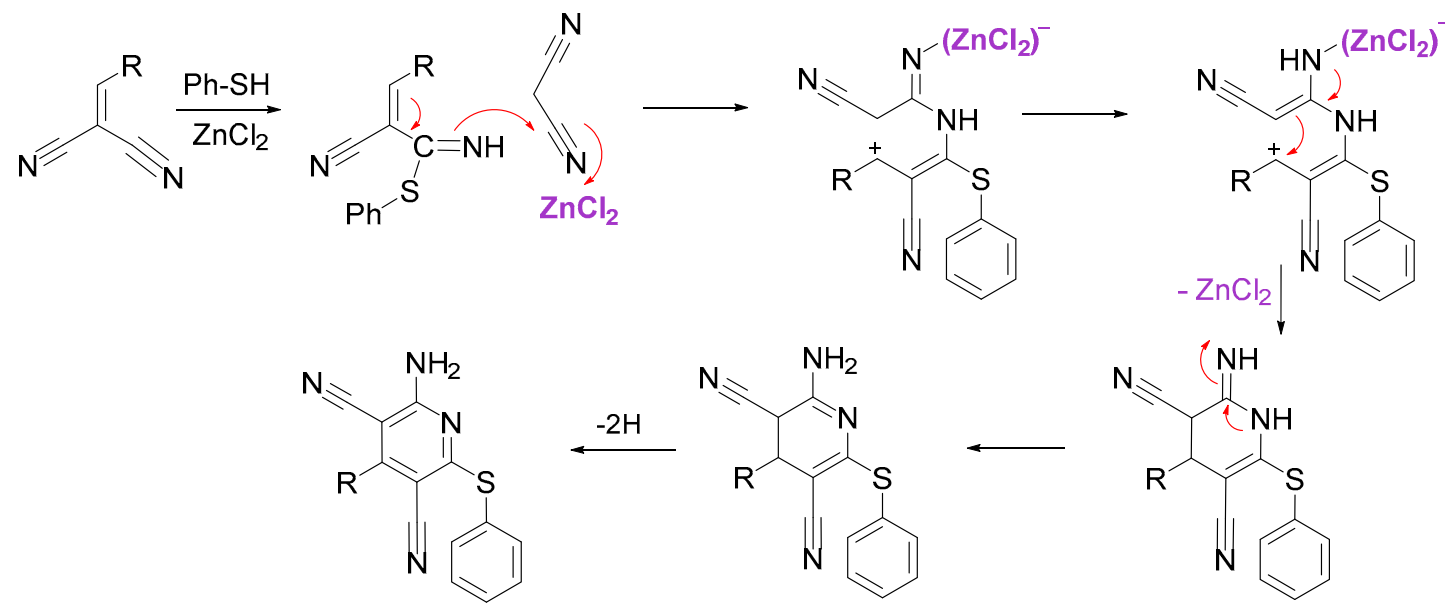

Figure 5. Reaction mechanism theorized when the Lewis acid $\mathrm{ZnCl}_{2}$ was used.

Subsequently, other authors used the same approach but using different Lewis acids. Kottawar and colleagues used scandium triflate to produce highly substituted pyridines. In this case, the yields of the reaction were subject to the used aldehyde, but they performed the reaction on a great variety of aldehydes to furnish a good library of data in the production of 3,5-dicyanopyridines [88]. The increasingly eco-friendly requirements for synthetic protocols pushed several researchers to also look for new materials and conditions. Takale and co-workers [89] investigated the use of iodoxybenzoic acid (IBX) in aqueous media as an oxidant catalyst. The activity of IBX was compared with other compounds such as $\beta$-cyclodextrin, ceric ammonium nitrate or sulfate, tetrabutylammonium hydrogen sulphate, urea hydrogen peroxide, and cupreous chloride at reflux conditions for 3-5 h, but the yields of recovered product were $32-60 \%$, while with IBX at $70{ }^{\circ} \mathrm{C}$, for a $1.5 \mathrm{~h}$ reaction time, the yield was $80 \%$. Additionally, the catalyst could be recovered and reused as it maintains its catalytic property. Thimmaiah and colleagues [90] set up a multicomponent reaction for the production of 2-amino-3,5-dicarbonitrile-6-thio-pyridines using heterogeneous catalysis by $\mathrm{Zn}(\mathrm{II})$ or a $\mathrm{Cd}(\mathrm{II})$ metal-organic framework (MOF). The advantages of the method were the tolerability of different functional groups present on the substrates, the recovery and reuse of the catalysts, and the fact that the reaction does not necessitate the use of any organic solvent. Moreover, in these conditions, the reaction requires less reaction time (30-60 $\mathrm{min})$, with, in general, very high yields of the product isolated by column chromatography.

Among the nanoparticle materials, $\mathrm{CuI}$ nanoparticles were also used as a worthwhile and reusable catalyst supply and eco-friendly procedure for the synthesis of 2-amino-3,5-dicyano-6-sulfanyl pyridine derivatives. The products were obtained, in the better conditions, using $\mathrm{CuI}$ with a high specific surface area and approximately crystalline size of $60 \mathrm{~nm}$ in ethanol/water under reflux conditions. The reaction took $100 \mathrm{~min}$ and via a multicomponent reaction of 4-chlorobenzaaldehyde, malononitrile, 
and thiophenol under reflux conditions, gave a $90 \%$ yield on the isolated product. The method presented is mild, efficient, inexpensive, and satisfactory to give the products in the presence of novel nanoscale materials [91].

Another approach to furnish this class of compounds was the use of ionic liquids. This approach has the advantage of the use of solvents with very low vapor pressure, good thermal stability, and the possibility to recycle and reuse them. The use of the ionic liquids is strategic also because gas, and in particular oxygen, can be present in the solvent at a greater concentration versus other organic solvents, allowing the easy dehydrogenation of 1,4-dihydropyridines leading to the pyridine derivatives by aromatization of the intermediate. Tian and Guo used 1-butyl-3-methylimidazolium tetrafluoroborate ([bmim $\left.] \mathrm{BF}_{4}\right)$ as an ionic liquid, which gave a higher yield of 2-amino-4-phenyl-6(phenylsulfanyl)-3,5-dicyanopyridines with respect to the corresponding chlorine or bromine ionic halide liquids [92]. In this case, the reaction was performed with the three-component approach, aromatic aldehyde, malononitrile, and thiophenol, at $50^{\circ} \mathrm{C}$. The advantages of the method were the very high yields $(78-89 \%)$, the short reaction time (20-30 $\mathrm{min}$ ) together with high selectivity and milder reaction conditions, and the recovery and reuse of the solvent.

Other authors used 2-hydroxyethylammonium acetate (2-HEAA) as an ionic liquid for the multicomponent reaction [93]. By using 2-HEAA, the reaction was kept at room temperature for $5 \mathrm{~min}$. Water was added to work up the reaction mixture from which the product was filtered off and the ionic liquid recovered after evaporation of the filtrate and drying at $10{ }^{\circ} \mathrm{C}$ under vacuum. The reuse of the solvents, recovered from a previous reaction batch, led to obtaining the desired product with an almost quantitative yield in the usual time. The authors hypothesized a mutual activation of the substrates and the ionic liquid, as shown in Figure 6.

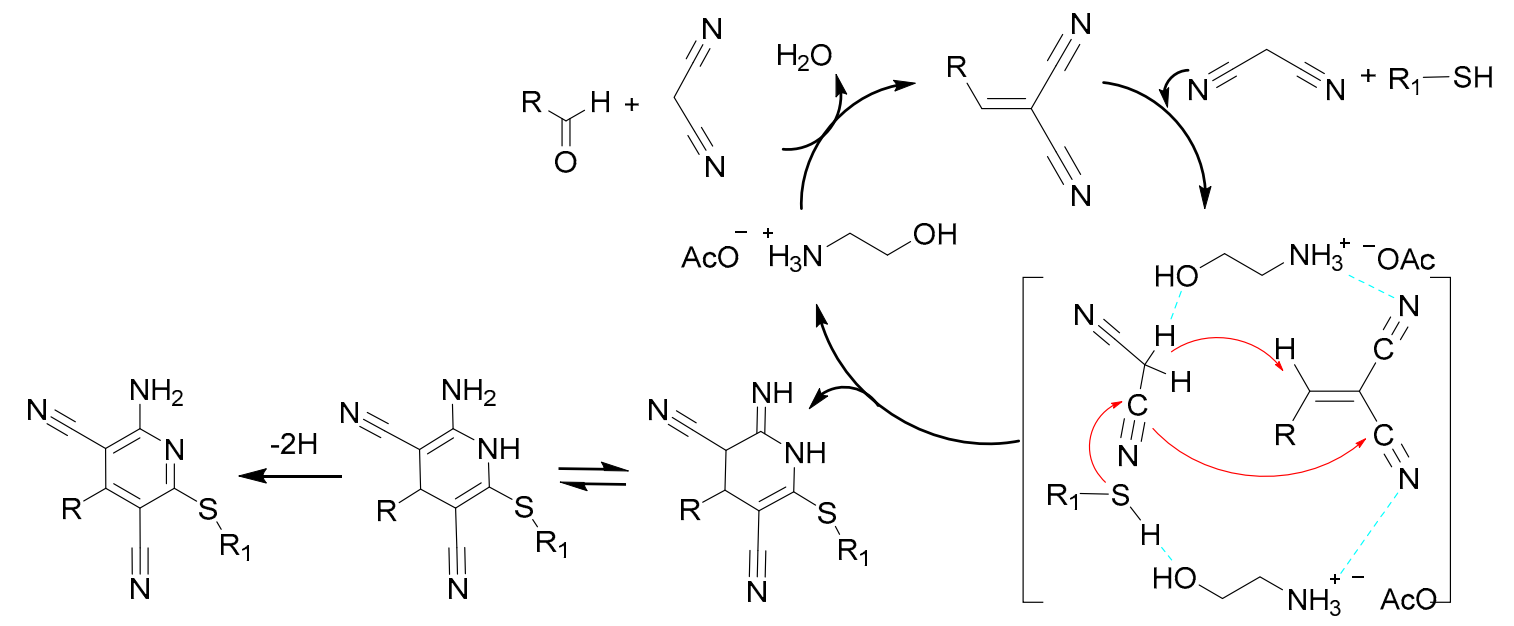

Figure 6. Reaction mechanism hypothesized for the mutual activation of the substrates and the ionic liquid.

In 2008, a patent (WO/2005/105778) by Otsuka Pharmaceutical reported the synthesis of 4-amino-5-cyanopyrimidine derivatives as potent $\mathrm{A}_{2 \mathrm{~A}} \mathrm{AR}$ agonists (second series of derivatives). Compounds were obtained through the synthesis of the intermediate 2-mercapto-4-substituted pyrimidine VI (Scheme 3). The scaffold was obtained using a previously reported procedure [94], by reaction of the useful substituted benzaldehyde with malononitrile, using ethanol as solvent, and an equimolar amount of an organic base, such as piperidine, at room temperature to give the 2-(4-substitutedbenzylidene)malononitrile. The latter compound was reacted with thiourea [95] in ethanol and in the presence of sodium ethoxide at reflux to obtain a mixture of pyrimidine or dehydropyrimidine derivatives $\mathbf{V}$ and VI. The reaction of the mixture of compounds with the suitable alkyl-aryl-halide in DMF as solvent, and in the presence of sodium bicarbonate as the base at room temperature, furnished the desired final compounds as 2-alkylthiopyrimidines VIII or 
2-alkylthiodehydropyrimidines VII. The dihydro compound $\mathbf{V}$ can be transformed to the pyrimidine derivative VI by an oxidation reaction.
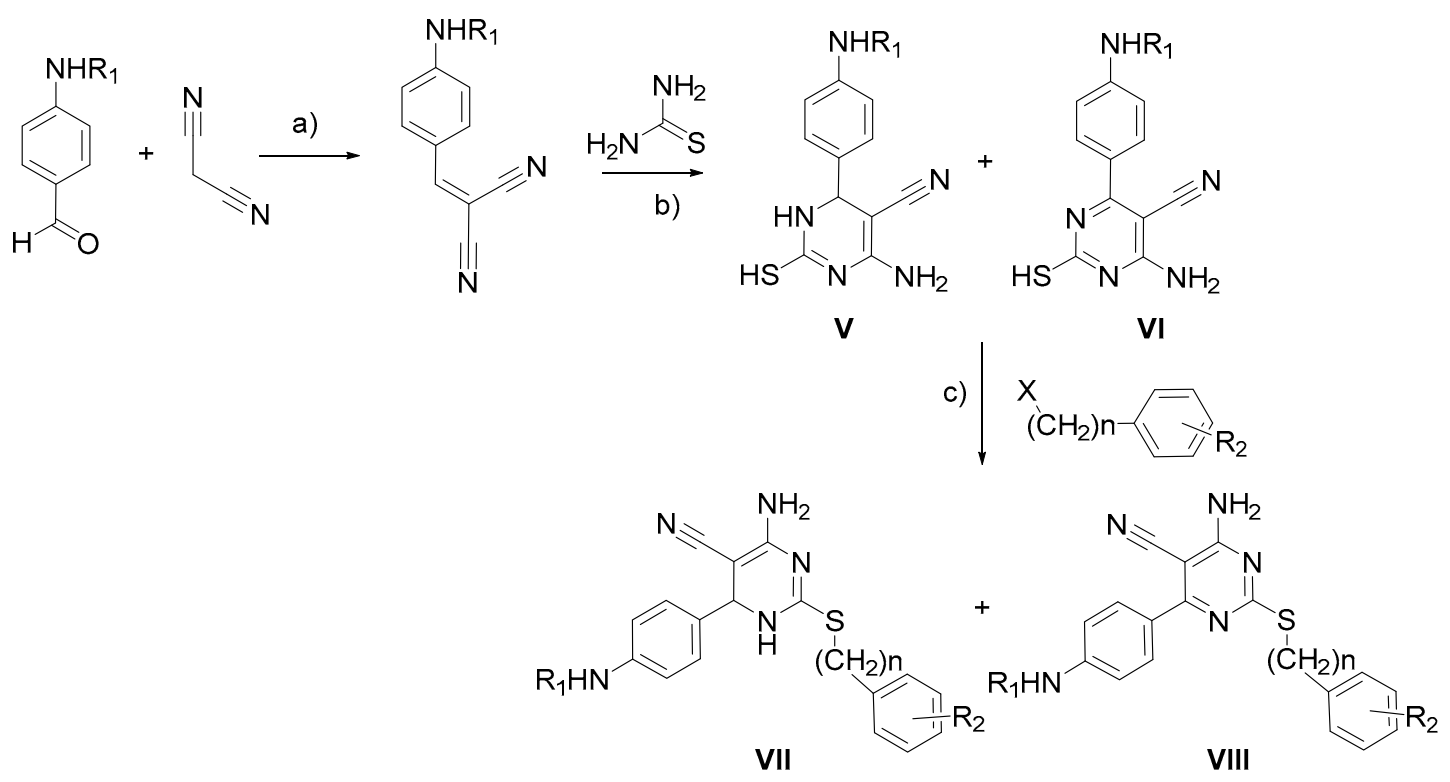

Scheme 3. Synthetic route for the pyrimidine derivatives with agonist properties at ARs. Reagents and conditions: a) piperidine, EtOH, r.t.; b) EtONa, EtOH, reflux; c) $\mathrm{NaHCO}_{3}$, DMF, r.t.

Treatment with N-bromosuccinimide (NBS) in ethanol or using 2,3-dichloro-5,6dicyanobenzoquinone (DDQ) in dioxane at reflux transformed the dehydro derivative $\mathbf{V}$ in the oxidized compound VI. Alternatively, the final compound could also be obtained by reaction of the thiourea with the alkyl-aryl-halide through the S-alkyl isothioureas IX. The reaction was performed in ethanol in the presence of a base or an acid at $60^{\circ} \mathrm{C}$. The intermediate was obtained as a free form or a salt form [96]. The S-alkyl isothioureas IX was then reacted with the benzylidene-malononitriles in ethanol and in the presence of sodium bicarbonate to furnish the desired compounds VIII (Scheme 4) [97].

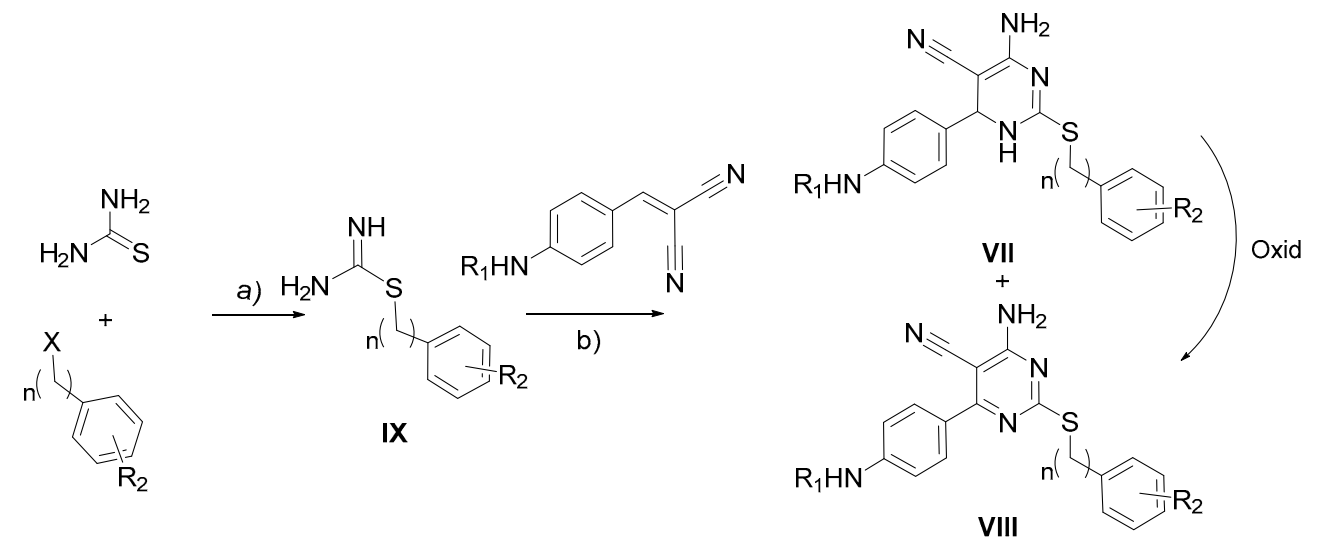

Scheme 4. Alternative route for the synthesis of the pyrimidine derivatives. Reagents and conditions:

a) base/acid, $\mathrm{EtOH}, 60{ }^{\circ} \mathrm{C}$; b) $\mathrm{NaHCO}_{3}, \mathrm{EtOH}$.

Starting from 2008, Cosimelli and coworkers published a series of compounds with agonist properties for ARs characterized by a common 6-alkoxypyrimidine scaffold $[79,80,98]$. The synthesis of such compounds was obtained by alkylation of the sulfur atom in the 2-position of the commercially available 4-amino-6-hydroxy-2-mercaptopyrimidine with the suitable alkyl halide in an aqueous solution of sodium hydroxide (Scheme 5). With the aim at alkylating the oxygen atom at 6-position, 
the 2-S-alkyl pyrimidines where then reacted with the suitable alkyl halide in DMF and excess of potassium carbonate. The reaction furnished a mixture of $\mathrm{O}$ - or $\mathrm{N}$-alkylated derivatives due to the keto-enolic equilibrium forms present of the reagent. Finally, the O-alkylated derivatives were reacted with the opportune anhydride and concentrated sulfuric acids as catalyst.

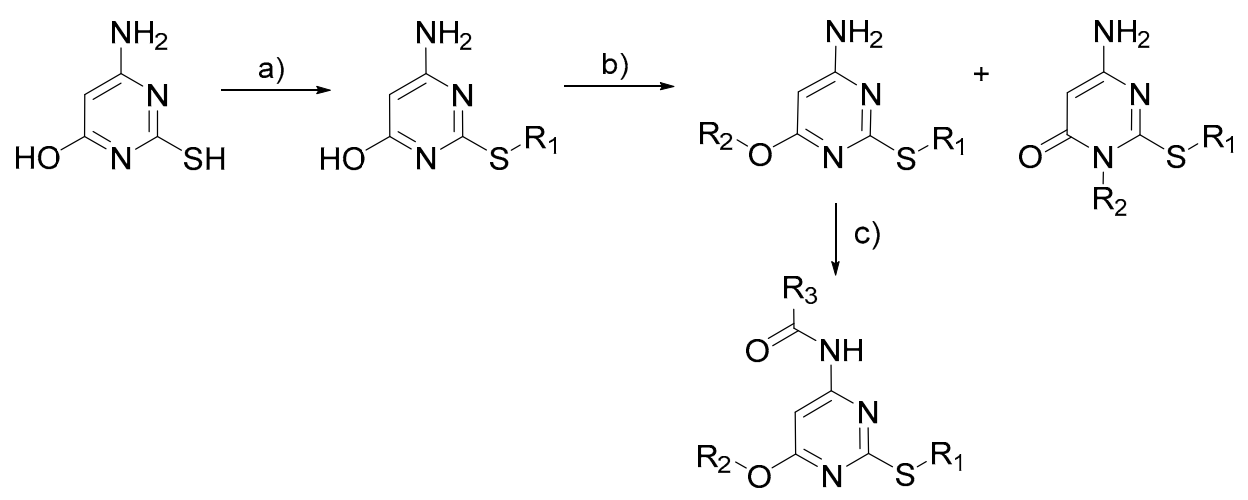

Scheme 5. Synthesis for the 6-alkoxy-pyrimidines. Reagents and conditions: a) alkyl/alkyl-aryl halide, $1 \mathrm{M} \mathrm{NaOH}, 50-55{ }^{\circ} \mathrm{C}$; b) alkyl/alkyl-aryl halide, anhydrous DMF, excess $\mathrm{K}_{2} \mathrm{CO}_{3}$, reflux; c) anhydride, catalytic conc $\mathrm{H}_{2} \mathrm{SO}_{4}, 50-60^{\circ} \mathrm{C}$.

The identification of non-nucleoside agonists with new scaffolds is very interesting, especially from the synthetic point of view. In fact, before the discovery of the pyridine and pyrimidine derivatives, all AR agonists were adenosine derivatives. Their synthesis is very complex and concerns two different so-called divergent or convergent approaches. In the first, a nucleoside is modified to obtain adenosine derivatives. An example is the synthesis of the full agonist 2-substituted NECA derivatives that can be obtained in about nine steps from guanosine to get the intermediate useful for the synthesis of compounds bearing a substitution in the 2-position, which is important for the selectivity of these compounds versus $A_{2 A} / A_{3}$ AR subtypes [99]. In the "convergent approach", the nucleosides are obtained by a glycosylation reaction through a modified nitrogen heterocyclic base and a suitable sugar both obtained after modification of commercially available bases and sugars, in different synthetic steps. The disadvantage of this method is that a mixture of different anomeric and isomeric compounds could be obtained based on coupling conditions, heterocyclic base, and sugar structures and reactivity [100,101]. Basically, nucleoside production consists of several synthetic passages, which involve the purification of the products with relatively complex methods and yields of the final products that could be very low due to the formation of side compounds.

The synthesis of nucleoside analogues furnished very potent and selective AR agonists that are actually used as tools to study ARs, and several examples are in clinical trials but in general with poor pharmacokinetic properties and very complex synthetic routes for their realization $[4,14,18,61]$. Hence, the need to discover non-nucleosidic scaffolds gives the advantage of low-cost compounds obtained with simple and fast methods, and sometimes environmental friendly procedures and fewer waste products. The change in the production of nucleosidic compounds with respect to the non-nucleosidic ones leads to a reduction of the synthetic work, decreases the costs of the production of the new molecules, and, decreasing the amount of waste, reduces the impact on pollution and on the costs of side-product disposal.

\subsection{Molecular Modelling}

Currently, several X-Ray or cryo-EM structures of ARs in complex with nucleoside agonists are available, in particular of the $A_{2 A}$ [102-104] and $A_{1}$ [105] AR subtypes. In contrast, structural experimental data depicting the interaction between non-nucleoside agonists and the ARs are still lacking. Studies were reported describing the effect of mutations of the binding site (or its proximity) 
residues on the affinity and/or efficacy of AR ligands, in some cases with the comparison of the effects on nucleoside- and non-nucleoside agonist activity. These works suggested different ligand-receptor recognition patterns for these two families of AR agonists. Molecular modelling studies were hence performed to interpret these data and to simulate the potential non-nucleoside agonist conformations within the AR binding cavity [36,37,63,64,68,106-109].

The docking conformation suggested by the majority of modelling studies presents the purine/pyrimidine scaffold of the agonists positioned analogously to the purine core of the nucleoside agonists (X-Ray/cryo-EM data), between a conserved phenylalanine in the extracellular loop (EL) 2 (i.e., Phe171 in the $A_{1} A R$ ) and a conserved isoleucine in the transmembrane (TM) chain 7 (position 7.39 according to the Ballesteros and Weinstein numbering system [110]; in the $\mathrm{A}_{1} \mathrm{AR}$, this position is occupied by Ile274 [111]). Figure 7 shows the putative binding mode of Capadenoson (1) and LUF5834 (13) at the $A_{1} A R$. The exocyclic amine has a polar interaction with a glutamate residue in EL2 (i.e., Glu172 in $A_{1} A R$ ) that is conserved among all the AR subtypes apart from the $A_{3} A R$. The same amine and the cyano group next to this function have a polar interaction with the AR conserved asparagine in the 6.55 position (i.e., Asn 254 in the $\mathrm{A}_{1} \mathrm{AR}$ ), while the aromatic ring directly linked to the heterocyclic core points toward the depth of the cavity. The thioarylalkyl chain is oriented toward the extracellular environment. This arrangement appears the most suitable to interpret the activity of Capadenoson analogues at the $\mathrm{A}_{1} \mathrm{AR}$ or the Otsuka Pharmaceuticals pyrimidine-based $\mathrm{A}_{2 \mathrm{~A}} \mathrm{AR}$ agonists, since the aromatic ring directly linked to the heterocyclic core generally presents small substituents that may find space within the depth of the binding cavities with no detrimental effect on the compound arrangement.

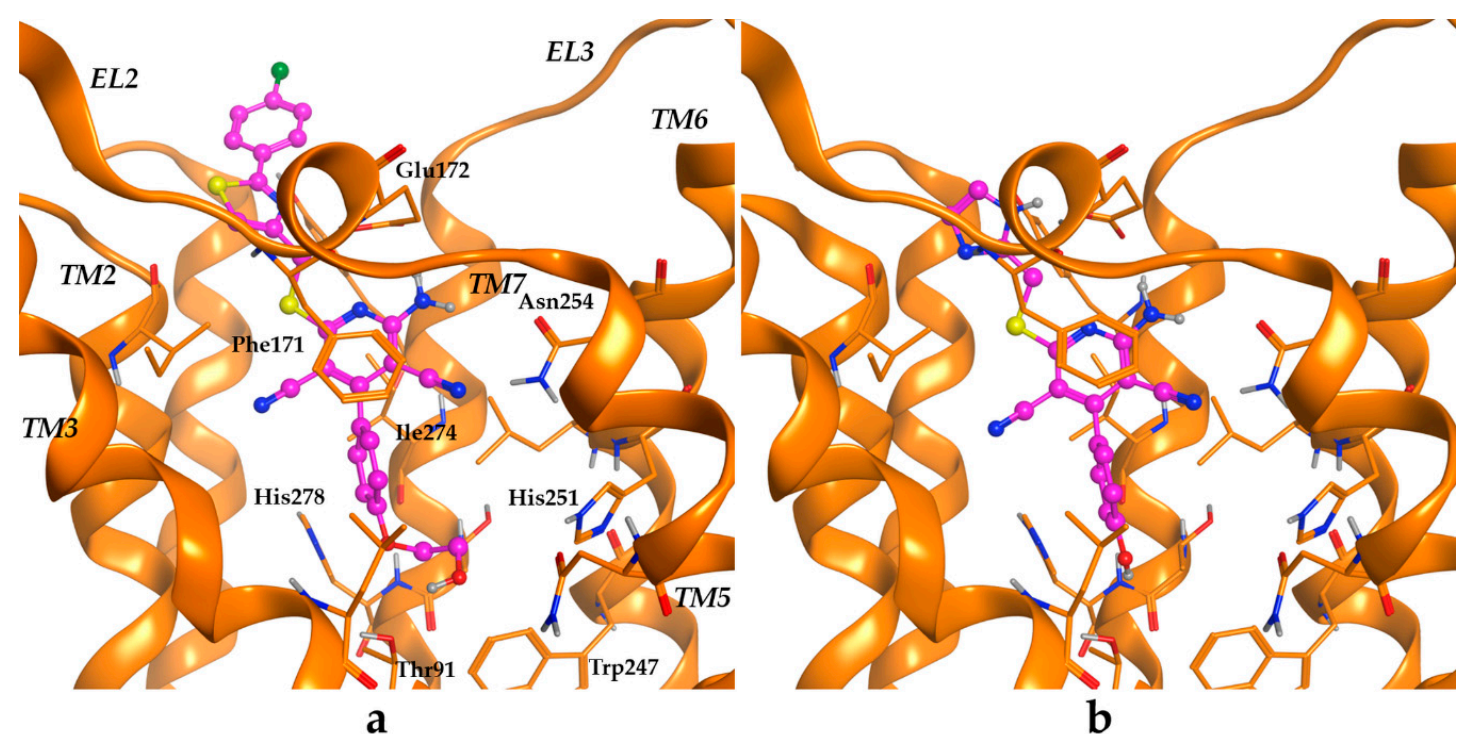

Figure 7. Putative binding mode of non-nucleoside agonists at the ARs. Panels $(\mathbf{a}, \mathbf{b})$ describe the potential binding mode of Capadenoson (1) and LUF5834 (13), respectively, at the $\mathrm{A}_{1} \mathrm{AR}$. Key receptor residues involved in ligand-target interaction are indicated.

The bulky thioarylalkyl chains of these compounds are located at the entrance of the binding cavities, where large amounts of space are available to accommodate these groups. The role of these chains to provide selectivity for a specific AR subtype seems critical since the kind of heterocycle inserted within this substituent modulates AR affinity. In fact, while the presence of an imidazole leads to compounds with nanomolar affinity for $A_{1}, A_{2 A}$, and $A_{2 B}$ subtypes, its replacement with a thiazole generally enhances $A_{1} A R$ selectivity. The presence of a pyridyl group appears favorable to improve $\mathrm{A}_{2 \mathrm{~A}} \mathrm{AR}$ affinity. Modeling studies have not clarified this feature since the thioarylalkyl chain may adopt several arrangements at the entrance of the binding cavity, with a consequent difficulty in the interpretation of the affinity data. The effect of the second cyano group (in the para-position with 
respect to the exocyclic amine) of the pyridines on the binding affinity has not been totally clarified as well, since compounds lacking this group (i.e., the corresponding pyrimidine derivatives) are endowed with nanomolar affinity for the respective ARs. Compounds bearing this function were suggested to have an additional interaction with a conserved histidine residue in position 7.43 (i.e., His278 in the $\left.\mathrm{A}_{1} \mathrm{AR}\right)$.

According to the above-described arrangement, the exocyclic amine would occupy the analogue position of the 6-amine group of nucleoside agonists. Hence, modifications of this group with the insertion of further substituents could follow the "rules" depicted by Structure-Activity Relationship (SAR) analyses of nucleoside analogues. As an example, the insertion of alkyl/cycloalkyl groups in the 6-amine of adenosine led to the development of the selective $\mathrm{A}_{1} \mathrm{AR}$ agonist cyclopentyladenosine (CPA). Analogously, the modification of the $\mathrm{A}_{1} \mathrm{AR}$ agonist Capadenoson (1) through the replacement of the exocyclic amine with a pyrrolidinyl group led to the development of Neladenoson (2), another $\mathrm{A}_{1} \mathrm{AR}$ agonist with improved selectivity versus the $\mathrm{A}_{2 \mathrm{~B}} \mathrm{AR}$ (see $\mathrm{EC}_{50}$ data of $\mathbf{1}$ and $\mathbf{2}$, Table 1). However, this rule appears to not always be respected in the case of non-nucleoside derivatives, since some above-described antagonists presenting analogue docking conformations were modified with the insertion of alkyl groups in the exocyclic amine but the obtained affinities at ARs were generally lower respect to the unmodified compounds [62].

Further arrangements were reported, with some relevant differences with respect to the above-described one. At the $\mathrm{A}_{2 \mathrm{~B}} \mathrm{AR}$, docking studies of pyridine-based agonists suggested an additional arrangement with the compounds (Figure 8a) [64,68,106,108].

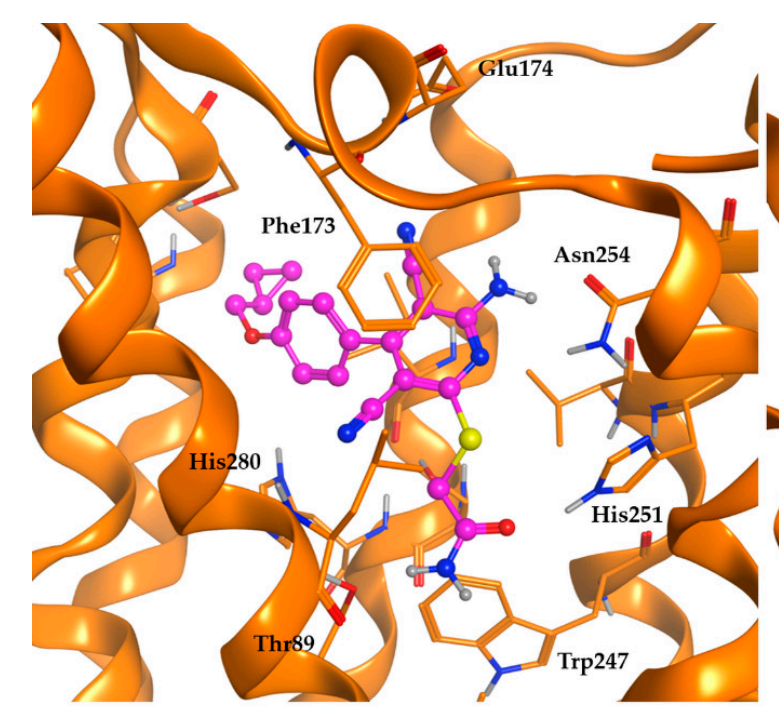

a

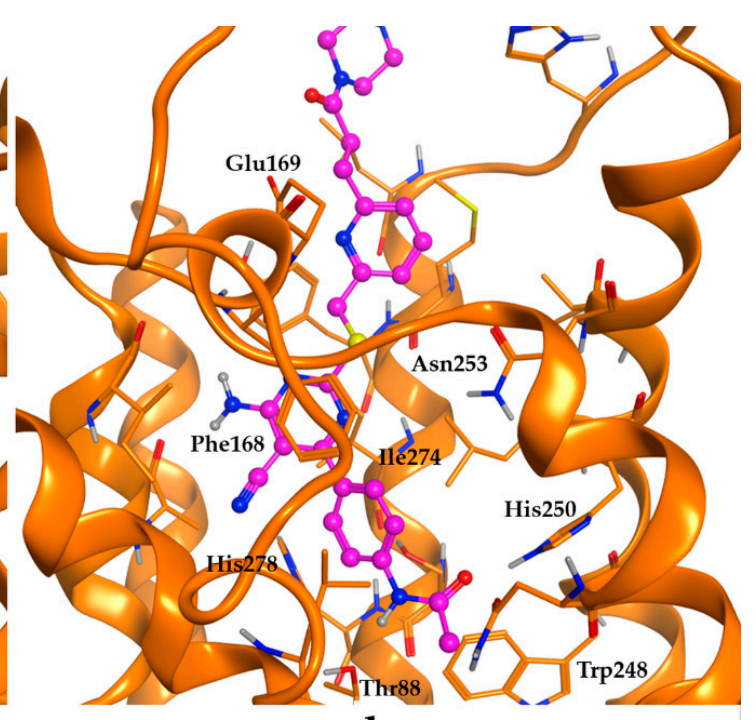

b

Figure 8. Putative binding mode of non-nucleoside agonists at the ARs. Panels $(\mathbf{a}, \mathbf{b})$ describe the potential alternative binding mode of non-nucleoside agonists at the $A_{2 B} A R(B A Y 60-6583,25)$ and at the $A_{2 A} A R$ (33), respectively. Key receptor residues involved in ligand-target interaction are indicated.

This docking conformation makes the heterocyclic core still be located in the center of the binding cavity, but the phenyl ring directly linked to it points toward the extracellular environment, while the thioarylalkyl chain is inserted in the depth of the cavity. The exocyclic amine again has a polar interaction with a glutamate residue in EL2 (i.e., Glu174 in $\mathrm{A}_{2 \mathrm{~B}} \mathrm{AR}$ ), while the polar interaction with the conserved asparagine 6.55 (Asn254 in the $\mathrm{A}_{2 \mathrm{~B}} \mathrm{AR}$ ) is given by the exocyclic amine and the nitrogen atom of the pyridine core, while the cyan group next to the exocyclic amine points toward the extracellular space. However, this arrangement appears possible only for derivatives presenting a small thioarylalkyl group. A further docking conformation was observed at the $\mathrm{A}_{2 \mathrm{~A}} \mathrm{AR}$ for the Otsuka Pharmaceutical pyrimidine-based agonists (Figure $8 b$ ) [109]. This conformation is an upside-down version of the 
general binding mode described above, with the thioarylalkyl group externally located and the phenyl ring in the depth of the cavity. The exocyclic amine interacts with TM2 residues, while the cyano group points toward the conserved histidine in the 7.43 position (i.e., His278 in the $\mathrm{A}_{2 \mathrm{~A}} \mathrm{AR}$ ). The polar interaction with the conserved asparagine in the 6.55 position (i.e., Asn253 in the $\mathrm{A}_{2 \mathrm{~A}} \mathrm{AR}$ ) is given by one of the nitrogen atoms of the heterocyclic core. This arrangement could be in agreement with the affinity data, but its occurrence apparently depends on the arrangement of the EL2 glutamate residue (i.e., Glu169 in $\left.\mathrm{A}_{2 \mathrm{~A}} \mathrm{AR}\right)$ [109].

Experimental (X-Ray/cryo-EM) data would be of great use for interpreting the biological activity of these compounds and for the design of further simplified agonists with high affinity, i.e., for the $\mathrm{A}_{3} \mathrm{AR}$, the only AR subtype at which the above-described non-nucleoside agonist presents low or null activity.

\section{Conclusions}

Agonists of the ARs were only analogues of nucleoside adenosine until the discovery of the agonist properties of some pyridine derivatives in the early 2000s. This discovery prompted researchers to identify new non-nucleoside molecules endowed with increased activity and/or selectivity compared to the various AR subtypes, due to their easy synthesis with respect to the production of nucleosides, especially from the industrial point of view.

This field appears promising, since on the one hand, selective A1, A2A, and A2B AR non-nucleoside agonists have been found only with two heterocyclic scaffolds (pyridine and pyrimidine), On the other hand, selective non-nucleoside agonists of the $\mathrm{A}_{3} \mathrm{AR}$ subtype have not been yet identified, leaving this goal still open. Finally, the understanding of the binding mode of non-nucleoside structures at the AR cavities could significantly help the design of novel agonists based on a simplified structure, with advantages due to the possibility of exploring different scaffolds and various substituents, which may also lead to good drug-like properties.

Author Contributions: D.D.B., C.L., and R.V. worked on the original draft preparation and data curation; M.B., A.M.N., G.M., and A.S. contributed to the writing and editing of the manuscript.

Funding: This work was supported by the Fondo di Ricerca di Ateneo (University of Camerino) and by a grant of the Italian Ministry for University and Research (PRIN 2015 N $^{\circ}$ 2015E8EMCM_008).

Conflicts of Interest: The authors declare no conflict of interest.

\section{References}

1. Fredholm, B.B.; IJzerman, A.P.; Jacobson, K.A.; Klotz, K.-N.; Linden, J. International Union of Pharmacology. XXV. Nomenclature and classification of adenosine receptors. Pharm. Rev. 2001, 53, 527-552. [PubMed]

2. Robeva, A.S.; Woodard, R.L.; Jin, X.; Gao, Z.; Bhattacharya, S.; Taylor, H.E.; Rosin, D.L.; Linden, J. Molecular characterization of recombinant human adenosine receptors. Drug Dev. Res. 1996, 39, 243-252. [CrossRef]

3. Fredholm, B.B.; IJzerman, A.P.; Jacobson, K.A.; Linden, J.; Muller, C.E. International Union of Basic and Clinical Pharmacology. LXXXI. Nomenclature and classification of adenosine receptors-an update. Pharm. Rev. 2011, 63, 1-34. [CrossRef] [PubMed]

4. Borea, P.A.; Gessi, S.; Merighi, S.; Vincenzi, F.; Varani, K. Pharmacology of adenosine receptors: The state of the art. Physiol. Rev. 2018, 98, 1591-1625. [CrossRef] [PubMed]

5. Cristalli, G.; Volpini, R. Adenosine receptors: Chemistry and pharmacology. Curr. Top. Med. Chem. 2003, 3, 355-469. [CrossRef] [PubMed]

6. Jacobson, K.A.; Gao, Z.G. Adenosine receptors as therapeutic targets. Nat. Rev. Drug. Discov. 2006, 5, 247-264. [CrossRef] [PubMed]

7. Sperlagh, B.; Vizi, E.S. The role of extracellular adenosine in chemical neurotransmission in the hippocampus and basal ganglia: Pharmacological and clinical aspects. Curr. Top. Med. Chem. 2011, 11, 1034-1046. [CrossRef]

8. Headrick, J.P.; Ashton, K.J.; Rose'meyer, R.B.; Peart, J.N. Cardiovascular adenosine receptors: Expression, actions and interactions. Pharm. Ther. 2013, 140, 92-111. [CrossRef] [PubMed] 
9. Dal Ben, D.; Antonioli, L.; Lambertucci, C.; Fornai, M.; Blandizzi, C.; Volpini, R. Purinergic ligands as potential therapeutic Tools for the treatment of inflammation-related intestinal diseases. Front. Pharm. 2018, 9, 212. [CrossRef]

10. Antonioli, L.; Colucci, R.; Pellegrini, C.; Giustarini, G.; Tuccori, M.; Blandizzi, C.; Fornai, M. The role of purinergic pathways in the pathophysiology of gut diseases: Pharmacological modulation and potential therapeutic applications. Pharm. Ther. 2013, 139, 157-188. [CrossRef]

11. Vallon, V.; Osswald, H. Adenosine receptors and the kidney. In Adenosine Receptors in Health and Disease; Springer: Berlin/Heidelberg, Germany, 2009; pp. 443-470.

12. Johnston-Cox, H.A.; Yang, D.; Ravid, K. Physiological implications of adenosine receptor-mediated platelet aggregation. J. Cell. Physiol. 2011, 226, 46-51. [CrossRef] [PubMed]

13. Linden, J. Regulation of leukocyte function by adenosine receptors. Adv. Pharm. 2011, 61, 95-114.

14. Chen, J.-F.; Eltzschig, H.K.; Fredholm, B.B. Adenosine receptors as drug targets-What are the challenges? Nat. Rev. Drug Discov. 2013, 12, 265-286. [CrossRef] [PubMed]

15. CVT. CV Therapeutics and Astellas Announce FDA Approval for Lexiscan(TM) (regadenoson) Injection. Available online: http://www.cvt.com/PressRelease.aspx?releaseID=1128317 (accessed on 10 April 2008).

16. Kyowa Hakko Kirin. Approval for Manufacturing and Marketing of NOURIASTßTablets 20 mg, a Novel Antiparkinsonian Agent. Available online: http://www.kyowa-kirin.com/news_releases/2013/e20130325_04. html (accessed on 7 October 2019).

17. FDA. Drug Trials Snapshots: NOURIANZ. Available online: https://www.fda.gov/drugs/drug-trialssnapshots-nourianz (accessed on 7 October 2019).

18. Muller, C.E.; Jacobson, K.A. Recent developments in adenosine receptor ligands and their potential as novel drugs. Biochim. Biophys. Acta 2011, 1808, 1290-1308. [CrossRef]

19. Baraldi, P.G.; Cacciari, B.; Pineda de Las Infantas, M.J.; Romagnoli, R.; Spalluto, G.; Volpini, R.; Costanzi, S.; Vittori, S.; Cristalli, G.; Melman, N.; et al. Synthesis and biological activity of a new series of $N^{6}$-arylcarbamoyl, 2-(Ar)alkynyl- $N^{6}$-arylcarbamoyl, and N6-carboxamido derivatives of adenosine-5'- $N$-ethyluronamide as $\mathrm{A}_{1}$ and $\mathrm{A}_{3}$ adenosine receptor agonists. J. Med. Chem. 1998, 41, 3174-3185. [CrossRef] [PubMed]

20. Cristalli, G.; Volpini, R.; Vittori, S.; Camaioni, E.; Monopoli, A.; Conti, A.; Dionisotti, S.; Zocchi, C.; Ongini, E. 2-Alkynyl derivatives of adenosine- $5^{\prime}-N$-ethyluronamide: Selective $\mathrm{A}_{2}$ adenosine receptor agonists with potent inhibitory activity on platelet aggregation. J. Med. Chem. 1994, 37, 1720-1726. [CrossRef] [PubMed]

21. Cristalli, G.; Camaioni, E.; Vittori, S.; Volpini, R.; Borea, P.A.; Conti, A.; Dionisotti, S.; Ongini, E.; Monopoli, A. 2-Aralkynyl and 2-heteroalkynyl derivatives of adenosine-5' $-N$-ethyluronamide as selective $\mathrm{A}_{2 \mathrm{a}}$ adenosine receptor agonists. J. Med. Chem. 1995, 38, 1462-1472. [CrossRef] [PubMed]

22. Volpini, R.; Buccioni, M.; Dal Ben, D.; Lambertucci, C.; Lammi, C.; Marucci, G.; Ramadori, A.T.; Klotz, K.-N.; Cristalli, G. Synthesis and biological evaluation of 2-alkynyl- $N^{6}$-methyl-5'-N-methylcarboxamidoadenosine derivatives as potent and highly selective agonists for the human adenosine $\mathrm{A}_{3}$ receptor. J. Med. Chem. 2009, 52, 7897-7900. [CrossRef] [PubMed]

23. Lambertucci, C.; Antonini, I.; Buccioni, M.; Dal Ben, D.; Kachare, D.D.; Volpini, R.; Klotz, K.-N.; Cristalli, G. 8-Bromo-9-alkyl adenine derivatives as tools for developing new adenosine $\mathrm{A}_{2 \mathrm{~A}}$ and $\mathrm{A}_{2 \mathrm{~B}}$ receptors ligands. Bioorg. Med. Chem. 2009, 17, 2812-2822. [CrossRef] [PubMed]

24. Lambertucci, C.; Buccioni, M.; Dal Ben, D.; Kachler, S.; Marucci, G.; Spinaci, A.; Thomas, A.; Klotz, K.-N.; Volpini, R. New substituted 9-propyladenine derivatives as $\mathrm{A}_{2 \mathrm{~A}}$ adenosine receptor antagonists. Medchemcomm 2015, 6, 963-970. [CrossRef]

25. Lambertucci, C.; Spinaci, A.; Buccioni, M.; Dal Ben, D.; Ngouadjeu Ngnintedem, M.A.; Kachler, S.; Marucci, G.; Klotz, K.-N.; Volpini, R. New A $2 \mathrm{~A}$ adenosine receptor antagonists: A structure-based upside-down interaction in the receptor cavity. Bioorg. Chem. 2019, 92. [CrossRef] [PubMed]

26. Rosentreter, U.; Henning, R.; Bauser, M.; Krämer, T.; Vaupel, A.; Hübsch, W.; Dembowsky, K.; Salcher-Schraufstätter, O.; Stasch, J.P.; Krahn, T.; et al. Substituted 2-Thio-3,5-Dicyano-4-Aryl-6-Aminopyridines and the Use Thereof as Adenosine Receptor Ligands. U.S. Patent 7,135,486, 14 November 2006.

27. Rosentreter, U.; Krämer, T.; Shimada, M.; Hübsch, W.; Diedrichs, N.; Krahn, T.; Henninger, K.; Stasch, J.P. Substituted 2-Thio-3,5-Dicyano-4-Phenyl-6-Aminopyridines and their Use as Adenosine Receptor-Selective Ligands. U.S. Patent 7,045,631, 16 May 2006. 
28. Rosentreter, U.; Kramer, T.; Vaupel, A.; Hubsch, W.; Diedrichs, N.; Krahn, T.; Dembowsky, K.; Stasch, J.P.; Shimada, M. Substituted 2-Thio-3,5-Dicyano-4-Phenyl-6-Aminopyridines with Adenosine Receptor-Binding Activity and their Use Cardiovascular Preparations. U.S. Patent 7,078,417, 18 July 2006.

29. Nell, P.; Albrecht-Kupper, B.; Hübsch, W.; Wuttke, M.; Krahn, T.; Diedrichs, N.; Bischoff, H. Use of Adenosine A1 and/or Dual A1/A2B Agonists for Production of Medicaments for Treating Diseases. U.S. Patent Application No. 12/224,417, 25 February 2010.

30. Kato, M.; Sato, N.; Okada, M.; Uno, T.; Ito, N.; Takeji, Y.; Shinohara, H.; Fuwa, M. 4-Amino-5-Cyanopyrimidine Derivatives. Patent Application KR20070008715, 17 January 2007.

31. Beukers, M.W.; Chang, L.C.; von Frijtag Drabbe Kunzel, J.K.; Mulder-Krieger, T.; Spanjersberg, R.F.; Brussee, J.; IJzerman, A.P. New, non-adenosine, high-potency agonists for the human adenosine $\mathrm{A}_{2 \mathrm{~B}}$ receptor with an improved selectivity profile compared to the reference agonist $\mathrm{N}$-ethylcarboxamidoadenosine. J. Med. Chem. 2004, 47, 3707-3709. [CrossRef] [PubMed]

32. Chang, L.C.; von Frijtag Drabbe Kunzel, J.K.; Mulder-Krieger, T.; Spanjersberg, R.F.; Roerink, S.F.; van den Hout, G.; Beukers, M.W.; Brussee, J.; IJzerman, A.P. A series of ligands displaying a remarkable agonistic-antagonistic profile at the adenosine $\mathrm{A}_{1}$ receptor. J. Med. Chem. 2005, 48, 2045-2053. [CrossRef] [PubMed]

33. Heitman, L.H.; Mulder-Krieger, T.; Spanjersberg, R.F.; von Frijtag Drabbe Kunzel, J.K.; Dalpiaz, A.; IJzerman, A.P. Allosteric modulation, thermodynamics and binding to wild-type and mutant (T277A) adenosine $A_{1}$ receptors of LUF5831, a novel nonadenosine-like agonist. Br. J. Pharm. 2006, 147, 533-541. [CrossRef] [PubMed]

34. Lane, J.R.; Klaasse, E.; Lin, J.; van Bruchem, J.; Beukers, M.W.; IJzerman, A.P. Characterization of [ $\left.{ }^{3} H\right]$ LUF5834: A novel non-ribose high-affinity agonist radioligand for the adenosine $\mathrm{A}_{1}$ receptor. Biochem. Pharm. 2010, 80, 1180-1189. [CrossRef] [PubMed]

35. Louvel, J.; Guo, D.; Agliardi, M.; Mocking, T.A.; Kars, R.; Pham, T.P.; Xia, L.; de Vries, H.; Brussee, J.; Heitman, L.H.; et al. Agonists for the adenosine $\mathrm{A}_{1}$ receptor with tunable residence time. A Case for nonribose 4-amino-6-aryl-5-cyano-2-thiopyrimidines. J. Med. Chem. 2014, 57, 3213-3222. [CrossRef] [PubMed]

36. Louvel, J.; Guo, D.; Soethoudt, M.; Mocking, T.A.; Lenselink, E.B.; Mulder-Krieger, T.; Heitman, L.H.; IJzerman, A.P. Structure-kinetics relationships of Capadenoson derivatives as adenosine $\mathrm{A}_{1}$ receptor agonists. Eur. J. Med. Chem. 2015, 101, 681-691. [CrossRef] [PubMed]

37. Lane, J.R.; Klein Herenbrink, C.; van Westen, G.J.; Spoorendonk, J.A.; Hoffmann, C.; IJzerman, A.P. A novel nonribose agonist, LUF5834, engages residues that are distinct from those of adenosine-like ligands to activate the adenosine $\mathrm{A}_{2 \mathrm{~A}}$ receptor. Mol. Pharm. 2012, 81, 475-487. [CrossRef] [PubMed]

38. Sato, N.; Yuki, Y.; Shinohara, H.; Takeji, Y.; Ito, K.; Michikami, D.; Hino, K.; Yamazaki, H. A Novel Cyanopyrimidine Derivative. Patent Application KR20100111687, 15 October 2010.

39. Nell, P.G.; Albrecht-Kupper, B. The Adenosine $A_{1}$ Receptor and its Ligands. Prog. Med. Chem. 2009, 47, 163-201. [PubMed]

40. Kiesman, W.F.; Elzein, E.; Zablocki, J. A 1 adenosine receptor antagonists, agonists, and allosteric enhancers. In Adenosine Receptors in Health and Disease; Springer: Berlin/Heidelberg, Germany, 2009; pp. 25-58.

41. Baltos, J.A.; Vecchio, E.A.; Harris, M.A.; Qin, C.X.; Ritchie, R.H.; Christopoulos, A.; White, P.J.; May, L.T. Capadenoson, a clinically trialed partial adenosine $\mathrm{A}_{1}$ receptor agonist, can stimulate adenosine $\mathrm{A}_{2 \mathrm{~B}}$ receptor biased agonism. Biochem. Pharm. 2017, 135, 79-89. [CrossRef] [PubMed]

42. Bott-Flugel, L.; Bernshausen, A.; Schneider, H.; Luppa, P.; Zimmermann, K.; Albrecht-Kupper, B.; Kast, R.; Laugwitz, K.L.; Ehmke, H.; Knorr, A.; et al. Selective attenuation of norepinephrine release and stress-induced heart rate increase by partial adenosine $\mathrm{A}_{1}$ agonism. PLoS ONE 2011, 6, e18048. [CrossRef] [PubMed]

43. Sabbah, H.N.; Gupta, R.C.; Kohli, S.; Wang, M.; Rastogi, S.; Zhang, K.; Zimmermann, K.; Diedrichs, N.; Albrecht-Kupper, B.E. Chronic therapy with a partial adenosine $\mathrm{A}_{1}$-receptor agonist improves left ventricular function and remodeling in dogs with advanced heart failure. Circ. Heart Fail. 2013, 6, 563-571. [CrossRef] [PubMed]

44. Tendera, M.; Gaszewska-Zurek, E.; Parma, Z.; Ponikowski, P.; Jankowska, E.; Kawecka-Jaszcz, K.; Czarnecka, D.; Krzeminska-Pakula, M.; Bednarkiewicz, Z.; Sosnowski, M.; et al. The new oral adenosine $\mathrm{A}_{1}$ receptor agonist capadenoson in male patients with stable angina. Clin. Res. Cardiol. 2012, 101, 585-591. [CrossRef] [PubMed]

45. Clinicaltrials.gov. Capadenoson in Angina Pectoris. Available online: https://clinicaltrials.gov/ct2/show/ NCT00518921 (accessed on 7 October 2019). 
46. Albrecht-Kupper, B.E.; Leineweber, K.; Nell, P.G. Partial adenosine $\mathrm{A}_{1}$ receptor agonists for cardiovascular therapies. Purinergic Signal 2012, 8, 91-99. [CrossRef] [PubMed]

47. Clinicaltrials.gov. Available online: https://clinicaltrials.gov/ct2/show/NCT00568945 (accessed on 7 October 2019).

48. Bailey, I.R.; Laughlin, B.; Moore, L.A.; Bogren, L.K.; Barati, Z.; Drew, K.L. Optimization of Thermolytic Response to $\mathrm{A}_{1}$ Adenosine Receptor Agonists in Rats. J. Pharm. Exp. Ther. 2017, 362, 424-430. [CrossRef] [PubMed]

49. Baltos, J.A.; Gregory, K.J.; White, P.J.; Sexton, P.M.; Christopoulos, A.; May, L.T. Quantification of adenosine $\mathrm{A}_{1}$ receptor biased agonism: Implications for drug discovery. Biochem. Pharm. 2016, 99, 101-112. [CrossRef] [PubMed]

50. Meibom, D.; Albrecht-Kupper, B.; Diedrichs, N.; Hubsch, W.; Kast, R.; Kramer, T.; Krenz, U.; Lerchen, H.G.; Mittendorf, J.; Nell, P.G.; et al. Neladenoson bialanate hydrochloride: A prodrug of a partial adenosine $\mathrm{A}_{1}$ receptor agonist for the chronic treatment of heart diseases. Chem. Med. Chem. 2017, 12, 728-737. [CrossRef] [PubMed]

51. Voors, A.A.; Dungen, H.D.; Senni, M.; Nodari, S.; Agostoni, P.; Ponikowski, P.; Bax, J.J.; Butler, J.; Kim, R.J.; Dorhout, B.; et al. Safety and tolerability of neladenoson bialanate, a novel oral partial adenosine $\mathrm{A}_{1}$ receptor agonist, in patients with chronic heart failure. J. Clin. Pharm. 2017, 57, 440-451. [CrossRef]

52. Dinh, W.; Albrecht-Kupper, B.; Gheorghiade, M.; Voors, A.A.; van der Laan, M.; Sabbah, H.N. Partial adenosine $\mathrm{A}_{1}$ agonist in heart failure. Handb. Exp. Pharm. 2017, 243, 177-203.

53. Tamargo, J.; Caballero, R.; Delpon, E. New drugs in preclinical and early stage clinical development in the treatment of heart failure. Expert Opin. Investig. Drugs 2019, 28, 51-71. [CrossRef]

54. Rossignol, P.; Hernandez, A.F.; Solomon, S.D.; Zannad, F. Heart failure drug treatment. Lancet 2019, 393, 1034-1044. [CrossRef]

55. Deb, P.K.; Deka, S.; Borah, P.; Abed, S.N.; Klotz, K.-N. Medicinal chemistry and therapeutic potential of agonists, antagonists and allosteric modulators of $\mathrm{A}_{1}$ adenosine receptor: Current status and perspectives. Curr. Pharm. Des. 2019. [CrossRef] [PubMed]

56. Clinicaltrials.gov. A Trial to Study Neladenoson Bialanate Over 20 Weeks in Patients with Chronic Heart Failure with Preserved Ejection Fraction (PANACHE). Available online: https://www.clinicaltrials.gov/ct2/ show/NCT03098979 (accessed on 7 October 2019).

57. Clinicaltrials.gov. A Trial to Study Neladenoson Bialanate Over 20 Weeks in Patients with Chronic Heart Failure with Reduced Ejection Fraction (PANTHEON). Available online: https://www.clinicaltrials.gov/ct2/ show/NCT02992288 (accessed on 7 October 2019).

58. Voors, A.A.; Bax, J.J.; Hernandez, A.F.; Wirtz, A.B.; Pap, A.F.; Ferreira, A.C.; Senni, M.; van der Laan, M.; Butler, J. Safety and efficacy of the partial adenosine $A_{1}$ receptor agonist neladenoson bialanate in patients with chronic heart failure with reduced ejection fraction: a phase $\mathrm{Ilb}$, randomized, double-blind, placebo-controlled trial. Eur. J. Heart Fail. 2019. [CrossRef] [PubMed]

59. Shah, S.J.; Voors, A.A.; McMurray, J.J.V.; Kitzman, D.W.; Viethen, T.; Bomfim Wirtz, A.; Huang, E.; Pap, A.F.; Solomon, S.D. Effect of neladenoson bialanate on exercise capacity among patients with heart failure with preserved ejection fraction: a randomized clinical trial. JAMA 2019, 321, 2101-2112. [CrossRef] [PubMed]

60. Guo, M.; Gao, Z.G.; Tyler, R.; Stodden, T.; Li, Y.; Ramsey, J.; Zhao, W.J.; Wang, G.J.; Wiers, C.E.; Fowler, J.S.; et al. Preclinical Evaluation of the First Adenosine $A_{1}$ Receptor Partial Agonist Radioligand for Positron Emission Tomography Imaging. J. Med. Chem. 2018, 61, 9966-9975. [CrossRef]

61. Jacobson, K.A.; Tosh, D.K.; Jain, S.; Gao, Z.G. Historical and Current Adenosine Receptor Agonists in Preclinical and Clinical Development. Front. Cell Neurosci. 2019, 13, 124. [CrossRef] [PubMed]

62. Betti, M.; Catarzi, D.; Varano, F.; Falsini, M.; Varani, K.; Vincenzi, F.; Pasquini, S.; di Cesare Mannelli, L.; Ghelardini, C.; Lucarini, E.; et al. Modifications on the Amino-3,5-dicyanopyridine Core to Obtain Multifaceted Adenosine Receptor Ligands with Antineuropathic Activity. J. Med. Chem. 2019, 62, 6894-6912. [CrossRef] [PubMed]

63. Seibt, B.F.; Schiedel, A.C.; Thimm, D.; Hinz, S.; Sherbiny, F.F.; Muller, C.E. The second extracellular loop of GPCRs determines subtype-selectivity and controls efficacy as evidenced by loop exchange study at $\mathrm{A}_{2}$ adenosine receptors. Biochem. Pharmacol. 2013, 85, 1317-1329. [CrossRef] [PubMed]

64. Betti, M.; Catarzi, D.; Varano, F.; Falsini, M.; Varani, K.; Vincenzi, F.; Dal Ben, D.; Lambertucci, C.; Colotta, V. The aminopyridine-3,5-dicarbonitrile core for the design of new non-nucleoside-like agonists of the human adenosine $\mathrm{A}_{2 \mathrm{~B}}$ receptor. Eur. J. Med. Chem. 2018, 150, 127-139. [CrossRef] 
65. Eckle, T.; Krahn, T.; Grenz, A.; Kohler, D.; Mittelbronn, M.; Ledent, C.; Jacobson, M.A.; Osswald, H.; Thompson, L.F.; Unertl, K.; et al. Cardioprotection by ecto-5'-nucleotidase (CD73) and $\mathrm{A}_{2 \mathrm{~B}}$ adenosine receptors. Circulation 2007, 115, 1581-1590. [CrossRef] [PubMed]

66. Baraldi, P.G.; Tabrizi, M.A.; Fruttarolo, F.; Romagnoli, R.; Preti, D. Recent improvements in the development of $\mathrm{A}_{2 \mathrm{~B}}$ adenosine receptor agonists. Purinergic Signal. 2009, 5, 3-19. [CrossRef] [PubMed]

67. Schiedel, A.C.; Hinz, S.; Thimm, D.; Sherbiny, F.; Borrmann, T.; Maass, A.; Muller, C.E. The four cysteine residues in the second extracellular loop of the human adenosine $\mathrm{A}_{2 \mathrm{~B}}$ receptor: role in ligand binding and receptor function. Biochem. Pharm. 2011, 82, 389-399. [CrossRef] [PubMed]

68. Thimm, D.; Schiedel, A.C.; Sherbiny, F.F.; Hinz, S.; Hochheiser, K.; Bertarelli, D.C.G.; Maass, A.; Müller, C.E. Ligand-Specific binding and activation of the human adenosine $A_{2 B}$ receptor. Biochemistry 2013, 52, 726-740. [CrossRef] [PubMed]

69. Hinz, S.; Lacher, S.K.; Seibt, B.F.; Muller, C.E. BAY60-6583 acts as a partial agonist at adenosine $A_{2 B}$ receptors. J. Pharm. Exp. Ther. 2014, 349, 427-436. [CrossRef] [PubMed]

70. Tian, Y.; Piras, B.A.; Kron, I.L.; French, B.A.; Yang, Z. Adenosine 2B receptor activation reduces myocardial reperfusion injury by promoting anti-inflammatory macrophages differentiation via PI3K/Akt pathway. Oxid. Med. Cell. Longev. 2015, 2015, 585297. [CrossRef] [PubMed]

71. Ni, Y.; Liang, D.; Tian, Y.; Kron, I.L.; French, B.A.; Yang, Z. Infarct-Sparing effect of adenosine $A_{2 B}$ receptor agonist is primarily due to its action on splenic leukocytes via a PI3K/Akt/IL-10 pathway. J. Surg. Res. 2018, 232, 442-449. [CrossRef] [PubMed]

72. Johnston-Cox, H.; Koupenova, M.; Yang, D.; Corkey, B.; Gokce, N.; Farb, M.G.; LeBrasseur, N.; Ravid, K. The $\mathrm{A}_{2 \mathrm{~B}}$ adenosine receptor modulates glucose homeostasis and obesity. PLoS ONE 2012, 7, e40584. [CrossRef] [PubMed]

73. Hoegl, S.; Brodsky, K.S.; Blackburn, M.R.; Karmouty-Quintana, H.; Zwissler, B.; Eltzschig, H.K. Alveolar epithelial $\mathrm{A}_{2 \mathrm{~B}}$ adenosine receptors in pulmonary protection during acute lung injury. J. Immunol. 2015, 195, 1815-1824. [CrossRef]

74. Johnston-Cox, H.; Eisenstein, A.S.; Koupenova, M.; Carroll, S.; Ravid, K. The macrophage $\mathrm{A}_{2 \mathrm{~B}}$ adenosine receptor regulates tissue insulin sensitivity. PLoS ONE 2014, 9, e98775. [CrossRef]

75. Csoka, B.; Koscso, B.; Toro, G.; Kokai, E.; Virag, L.; Nemeth, Z.H.; Pacher, P.; Bai, P.; Hasko, G. A 2 B adenosine receptors prevent insulin resistance by inhibiting adipose tissue inflammation via maintaining alternative macrophage activation. Diabetes 2014, 63, 850-866. [CrossRef]

76. Chang, L.C.; Spanjersberg, R.F.; von Frijtag Drabbe Kunzel, J.K.; Mulder-Krieger, T.; van den Hout, G.; Beukers, M.W.; Brussee, J.; IJzerman, A.P. 2,4,6-trisubstituted pyrimidines as a new class of selective adenosine $\mathrm{A}_{1}$ receptor antagonists. J. Med. Chem. 2004, 47, 6529-6540. [CrossRef] [PubMed]

77. van Veldhoven, J.P.; Chang, L.C.; von Frijtag Drabbe Kunzel, J.K.; Mulder-Krieger, T.; Struensee-Link, R.; Beukers, M.W.; Brussee, J.; IJzerman, A.P. A new generation of adenosine receptor antagonists: from di- to trisubstituted aminopyrimidines. Bioorg. Med. Chem. 2008, 16, 2741-2752. [CrossRef] [PubMed]

78. Vidal, B.; Nueda, A.; Esteve, C.; Domenech, T.; Benito, S.; Reinoso, R.F.; Pont, M.; Calbet, M.; Lopez, R.; Cadavid, M.I.; et al. Discovery and characterization of 4'-(2-furyl)-N-pyridin-3-yl-4,5'-bipyrimidin-2'-amine (LAS38096), a potent, selective, and efficacious $\mathrm{A}_{2 \mathrm{~B}}$ adenosine receptor antagonist. J. Med. Chem. 2007, 50, 2732-2736. [CrossRef] [PubMed]

79. Cosimelli, B.; Greco, G.; Laneri, S.; Novellino, E.; Sacchi, A.; Trincavelli, M.L.; Giacomelli, C.; Taliani, S.; Da Settimo, F.; Martini, C. 4-amino-6-alkyloxy-2-alkylthiopyrimidine derivatives as novel non-nucleoside agonists for the adenosine $\mathrm{A}_{1}$ receptor. Chem. Biol. Drug Des. 2016, 88, 724-729. [CrossRef] [PubMed]

80. Bharate, S.B.; Singh, B.; Kachler, S.; Oliveira, A.; Kumar, V.; Bharate, S.S.; Vishwakarma, R.A.; Klotz, K.-N.; Gutierrez de Teran, H. Discovery of 7-(Prolinol-N-yl)-2-phenylamino-thiazolo[5,4-d]pyrimidines as novel non-nucleoside partial agonists for the $\mathrm{A}_{2 \mathrm{~A}}$ adenosine receptor: Prediction from molecular modeling. J. Med. Chem. 2016, 59, 5922-5928. [CrossRef] [PubMed]

81. Cosimelli, B.; Greco, G.; Ehlardo, M.; Novellino, E.; Da Settimo, F.; Taliani, S.; La Motta, C.; Bellandi, M.; Tuccinardi, T.; Martinelli, A.; et al. Derivatives of 4-amino-6-hydroxy-2-mercaptopyrimidine as novel, potent, and selective $\mathrm{A}_{3}$ adenosine receptor antagonists. J. Med. Chem. 2008, 51, 1764-1770. [CrossRef]

82. Dyachenko, V.D.; Krivokolysko, S.; Sharanin, Y.; Litvinov, V.P. New route to 6-amino-4-aryl-3,5-dicyanopyridine-2(1H)-thiones. Russ. J. Org. Chem. 1997, 33, 1014-1017. 
83. Dyachenko, V.D.; Krivokolysko, S.; Sharanin, Y.; Litvinov, V.P. Synthesis and recyclization of 4-aryl-2,6diamino-3,5-dicyano-4H-thiopyrans. Russ. J. Org. Chem. 1998, 34, 557-563.

84. Quintela, J.M.; Peinador, C.; Veiga, M.C.; Botana, L.M.; Alfonso, A.; Riguera, R. Synthesis, antihistaminic and cytotoxic activity of pyridothieno- and pyridodithienotriazines. Eur. J. Med. Chem. 1998, 33, 887-897. [CrossRef]

85. Dyachenko, V.D.; Litvinov, V.P. Michael reaction in synthesis of 6-amino-4-(4-butoxyphenyl)3,5-dicyanopyridine-2(1H)-thione. Chem. Heterocycl. Compd. 1998, 34, 188-194. [CrossRef]

86. Evdokimov, N.M.; Magedov, I.V.; Kireev, A.S.; Kornienko, A. One-step, three-component synthesis of pyridines and 1,4-dihydropyridines with manifold medicinal utility. Org. Lett. 2006, 8, 899-902. [CrossRef] [PubMed]

87. Sridhar, M.; Ramanaiah, B.C.; Narsaiah, C.; Mahesh, B.; Kumaraswamy, M.; Mallu, K.K.R.; Ankathi, V.M.; Shanthan Rao, P. Novel $\mathrm{ZnCl}_{2}$-catalyzed one-pot multicomponent synthesis of 2-amino-3,5-dicarbonitrile6-thio-pyridines. Tetrahedron Lett. 2009, 50, 3897-3900. [CrossRef]

88. Kottawar, S.S.; Siddiqui, S.A.; Bhusare, S.R. Scandium triflate-catalyzed one-pot multi-component synthesis of 2-amino-6-thiopyridine-3,5-dicarbonitriles. Heterocycl. Commun. 2012, 18, 249. [CrossRef]

89. Takale, S.; Patil, J.; Padalkar, V.; Pisal, R.; Chaskar, A. O-iodoxybenzoic acid in water: Optimized green alternative for multicomponent one-pot synthesis of 2-amino-3,5-dicarbonitrile-6-thiopyridines. J. Braz. Chem. Soc. 2012, 23, 966-969. [CrossRef]

90. Thimmaiah, M.; Li, P.; Regati, S.; Chen, B.; Zhao, J.C.-G. Multi-component synthesis of 2-amino-6-(alkylthio)pyridine-3,5-dicarbonitriles using $\mathrm{Zn}$ (II) and Cd(II) metal-organic frameworks (MOFs) under solvent-free conditions. Tetrahedron Lett. 2012, 53, 4870-4872. [CrossRef] [PubMed]

91. Safaei-Ghomi, J.; Ghasemzadeh, M.A. CuI nanoparticles: A highly active and easily recyclable catalyst for the synthesis of 2-amino-3,5-dicyano-6-sulfanyl pyridines. J. Sulfur Chem. 2013, 34, 233-241. [CrossRef]

92. Tian, J.; Guo, H. One-Pot Synthesis of 2-Amino-4-phenyl-6-(phenylsulfanyl)-3,5-dicyanopyridines in Ionic Liquids. Chin. J. Org. Chem. 2012, 32, 193-196. [CrossRef]

93. Sobhani, S.; Honarmand, M. 2-Hydroxyethylammonium acetate: A reusable task-specific ionic liquid promoting one-pot, three-component synthesis of 2-amino-3,5-dicarbonitrile-6-thio-pyridines. C. R. Chim. 2013, 16, 279-286. [CrossRef]

94. Emerson, W.S.; Patrick, T.M. The preparation of 2-thiophenealdehyde and some of its derivatives. J. Org. Chem. 1949, 14, 790-797. [CrossRef]

95. Daboun, H.A.; El-Reedy, A.M. A one step synthesis of new 4-aminopyrimidine derivatives: Preparation of tetrazolo- and s-triazolopyrimidines. Z. Nat. B 1983, 38, 1686. [CrossRef]

96. Urquhart, G.G.; Gates, J.W.J.; Connor, R. n-Dodecyl (lauryl) mercaptan. Org. Synth. 1941, $21,36$.

97. El-Sharabsy, S.A.; Gawad, S.M.A.; Hussain, S.M. Reactions with substituted acrylonitriles: A novel synthesis of polysubstituted pyrimidines. J. Prakt. Chem. 1989, 331, 207-211. [CrossRef]

98. Cosimelli, B.; Greco, G.; Laneri, S.; Novellino, E.; Sacchi, A.; Collina, S.; Rossi, D.; Cosconati, S.; Barresi, E.; Taliani, S.; et al. Studies on enantioselectivity of chiral 4-acetylamino-6-alkyloxy-2-alkylthiopyrimidines acting as antagonists of the human $\mathrm{A}_{3}$ adenosine receptor. Medchemcomm 2018, 9, 81-86. [CrossRef] [PubMed]

99. Cristalli, G.; Eleuteri, A.; Vittori, S.; Volpini, R.; Lohse, M.J.; Klotz, K.-N. 2-Alkynyl derivatives of adenosine and adenosine-5'-N-ethyluronamide as selective agonists at $\mathrm{A}_{2}$ adenosine receptors. J. Med. Chem. 1992, 35, 2363-2368. [CrossRef]

100. Cristalli, G.; Costanzi, S.; Lambertucci, C.; Taffi, S.; Vittori, S.; Volpini, R. Purine and deazapurine nucleosides: Synthetic approaches, molecular modelling and biological activity. IL Farm. 2003, 58, 193-204. [CrossRef]

101. Volpini, R.; Camaioni, E.; Vittori, S.; Barboni, L.; Lambertucci, C.; Cristalli, G. Synthesis of New Nucleosides by coupling of chloropurines with 2- and 3-deoxy derivatives of $\mathrm{N}$-methyl-D-ribofuranuronamide. Helv. Chim. Acta 1998, 81, 145-152. [CrossRef]

102. Lebon, G.; Warne, T.; Edwards, P.C.; Bennett, K.; Langmead, C.J.; Leslie, A.G.; Tate, C.G. Agonist-bound adenosine $\mathrm{A}_{2 \mathrm{~A}}$ receptor structures reveal common features of GPCR activation. Nature 2011, 474, 521-525. [CrossRef]

103. Xu, F.; Wu, H.; Katritch, V.; Han, G.W.; Jacobson, K.A.; Gao, Z.G.; Cherezov, V.; Stevens, R.C. Structure of an agonist-bound human $\mathrm{A}_{2 \mathrm{~A}}$ adenosine receptor. Science 2011, 332, 322-327. [CrossRef]

104. Lebon, G.; Edwards, P.C.; Leslie, A.G.; Tate, C.G. Molecular determinants of CGS21680 binding to the human adenosine $\mathrm{A}_{2 \mathrm{~A}}$ receptor. Mol. Pharm. 2015, 87, 907-915. [CrossRef] 
105. Draper-Joyce, C.J.; Khoshouei, M.; Thal, D.M.; Liang, Y.L.; Nguyen, A.T.N.; Furness, S.G.B.; Venugopal, H.; Baltos, J.A.; Plitzko, J.M.; Danev, R.; et al. Structure of the adenosine-bound human adenosine $\mathrm{A}_{1}$ receptor-Gi complex. Nature 2018, 558, 559-563. [CrossRef]

106. Dal Ben, D.; Buccioni, M.; Lambertucci, C.; Thomas, A.; Volpini, R. Simulation and comparative analysis of binding modes of nucleoside and non-nucleoside agonists at the $\mathrm{A}_{2 \mathrm{~B}}$ adenosine receptor. Silico Pharm. 2013, 1, 24. [CrossRef] [PubMed]

107. Li, J.; Jonsson, A.L.; Beuming, T.; Shelley, J.C.; Voth, G.A. Ligand-dependent activation and deactivation of the human adenosine $\mathrm{A}_{2 \mathrm{~A}}$ receptor. J. Am. Chem. Soc. 2013, 135, 8749-8759. [CrossRef] [PubMed]

108. Rodriguez, D.; Gao, Z.G.; Moss, S.M.; Jacobson, K.A.; Carlsson, J. Molecular docking screening using agonist-bound GPCR structures: Probing the $\mathrm{A}_{2 \mathrm{~A}}$ adenosine receptor. J. Chem. Inf. Model. 2015, 55, 550-563. [CrossRef] [PubMed]

109. Dal Ben, D.; Buccioni, M.; Lambertucci, C.; Marucci, G.; Santinelli, C.; Spinaci, A.; Thomas, A.; Volpini, R. Simulation and comparative analysis of different binding modes of Non-nucleoside agonists at the $\mathrm{A}_{2 \mathrm{~A}}$ adenosine receptor. Mol. Inf. 2016, 35, 403-413. [CrossRef] [PubMed]

110. Ballesteros, J.A.; Weinstein, H. Integrated methods for the construction of three-dimensional models and computational probing of structure-function relations in G protein-coupled receptors. Methods Neurosci. 1995, 25, 366-428.

111. Dal Ben, D.; Lambertucci, C.; Marucci, G.; Volpini, R.; Cristalli, G. Adenosine receptor modeling: What does the $\mathrm{A}_{2 \mathrm{~A}}$ crystal structure tell us? Curr. Top. Med. Chem. 2010, 10, 993-1018. [CrossRef] [PubMed]

(C) 2019 by the authors. Licensee MDPI, Basel, Switzerland. This article is an open access article distributed under the terms and conditions of the Creative Commons Attribution (CC BY) license (http://creativecommons.org/licenses/by/4.0/). 